\title{
As-Run Thermal Analysis of the GTL-1 Experiment Irradiated in the ATR South Flux Trap
}

\author{
Donna P. Guillen
}

May 2011

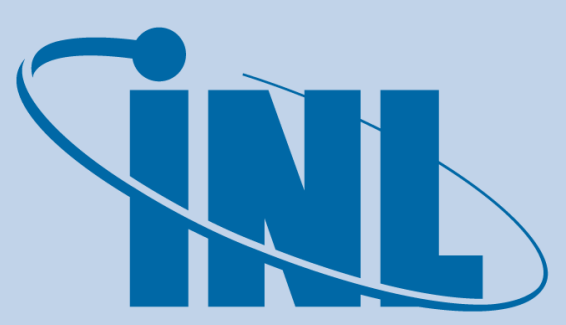

Idaho National Laboratory 


\section{DISCLAIMER}

This information was prepared as an account of work sponsored by an agency of the U.S. Government. Neither the U.S. Government nor any agency thereof, nor any of their employees, makes any warranty, expressed or implied, or assumes any legal liability or responsibility for the accuracy, completeness, or usefulness, of any information, apparatus, product, or process disclosed, or represents that its use would not infringe privately owned rights. References herein to any specific commercial product, process, or service by trade name, trade mark, manufacturer, or otherwise, does not necessarily constitute or imply its endorsement, recommendation, or favoring by the U.S. Government or any agency thereof. The views and opinions of authors expressed herein do not necessarily state or reflect those of the U.S. Government or any agency thereof. 


\title{
As-Run Thermal Analysis of the GTL-1 Experiment Irradiated in the ATR South Flux Trap
}

\author{
Donna P. Guillen
}

May 2011

\begin{abstract}
Idaho National Laboratory
Next Generation Nuclear Plant Project

Idaho Falls, Idaho 83415
\end{abstract}

Prepared for the

U.S. Department of Energy

Office of Nuclear Energy

Under DOE Idaho Operations Office

Contract DE-AC07-05ID14517 


\section{As-Run Thermal Analysis of the GTL-1 Experiment Irradiated in the ATR South Flux Trap}

INL/EXT-11-21975

May 2011

Prepared by:
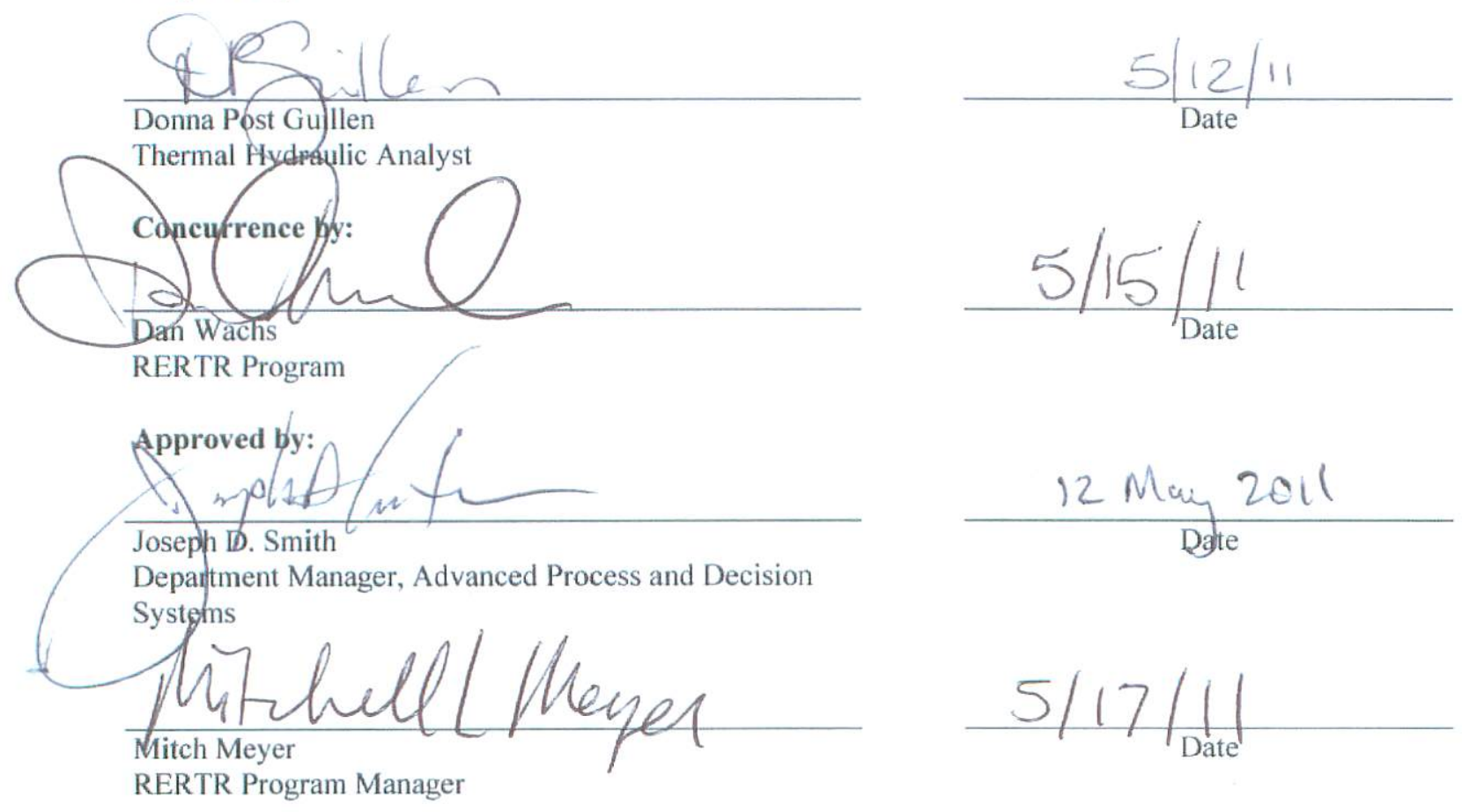



\section{ABSTRACT}

The GTL-1 experiment was conducted to assess corrosion performance of the proposed Boosted Fast Flux Loop booster fuel at heat flux levels $~ 30 \%$ above the design operating condition. Sixteen miniplates fabricated from $25 \%$ enriched, high-density $\left(4.8 \mathrm{~g}-\mathrm{U} / \mathrm{cm}^{3}\right) \mathrm{U}_{3} \mathrm{Si}_{2} / \mathrm{Al}$ dispersion fuel with 6061 aluminum cladding were subjected to peak beginning of cycle (BOC) heat fluxes ranging from $411 \mathrm{~W} / \mathrm{cm}^{2}$ to $593 \mathrm{~W} / \mathrm{cm}^{2}$. Miniplates fabricated with three different fuel variations (without fines, annealed, and with standard powder) exhibited negligible irradiation-induced swelling and a normal fission density gradient. Both the standard and the modified prefilm procedures produced hydroxide films that adequately protected the miniplates from excessive surface corrosion.

A detailed finite element model was constructed to calculate temperatures and heat flux for an as-run cycle average effective ATR south lobe power of 25.4 MW(t). Results of the thermal analysis are given at four times during the cycle: BOC at 0 effective full power days (EFPD), middle of cycle (MOC) at 18 EFPD, MOC at 36 EFPD, and end of cycle at 48.9 EFPD. The highest temperatures and heat fluxes occur at the BOC and decrease in a linear manner throughout the cycle.

Miniplate heat flux levels and fuel, cladding, hydroxide, and coolanthydroxide interface temperatures were calculated using the average hydroxide thickness on each miniplate measured during post-irradiation examination. The hydroxide layers are the largest on miniplates nearest to the core midplane, where heat flux and temperature are highest. The hydroxide layer thickness averages $20.4 \mu \mathrm{m}$ on the six hottest miniplates (B3, B4, C1, C2, C3, and C4). This tends to exacerbate the heating of these miniplates, since a thicker hydroxide layer reduces the heat transfer from the fuel to the coolant. The computational results indicate that fuel centerline temperature increases by approximately $2.25^{\circ} \mathrm{C}$ per $\mu \mathrm{m}$ of hydroxide thickness. Assuming EOC hydroxide layer thickness, these six hottest miniplates have the following thermal characteristics at BOC:

- Peak fuel centerline temperature $>300^{\circ} \mathrm{C}$

- Peak cladding temperature $>200^{\circ} \mathrm{C}$

- Peak hydroxide temperature $>190^{\circ} \mathrm{C}$

- Peak hydroxide-water interface temperature $>140^{\circ} \mathrm{C}$

- Peak heat flux $>565 \mathrm{~W} / \mathrm{cm}^{2}$. 


\section{CONTENTS}

ABSTRACT

ACRONYMS

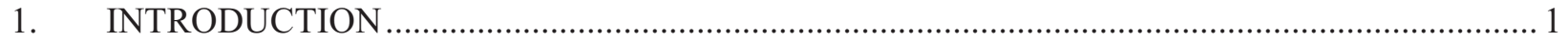

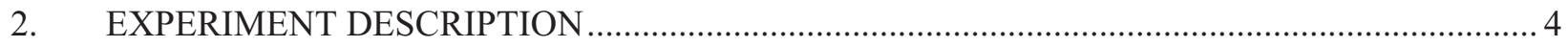

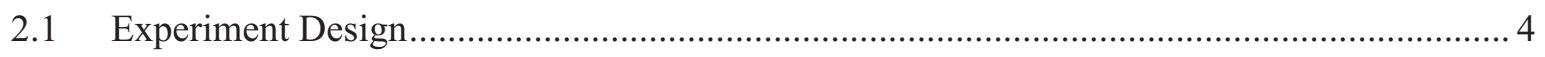

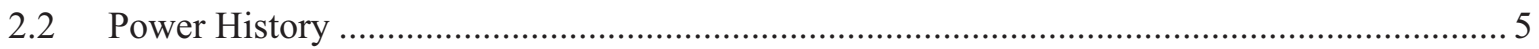

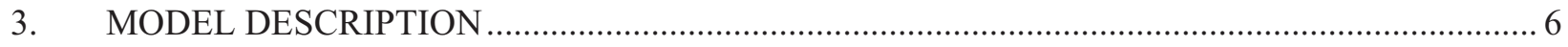

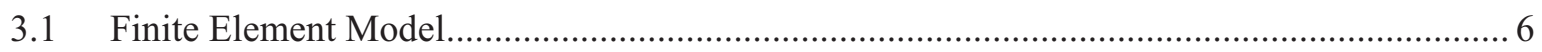

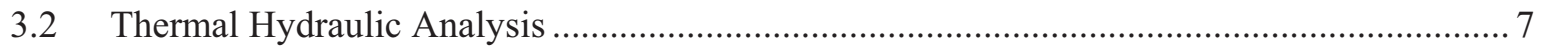

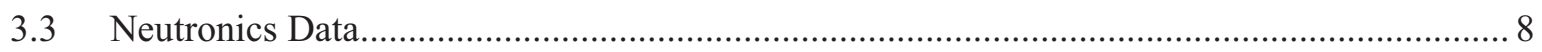

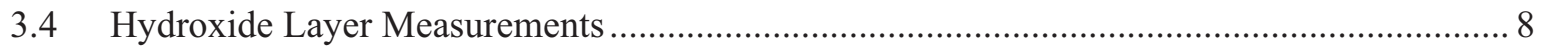

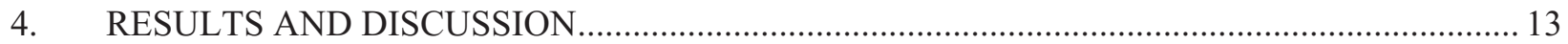

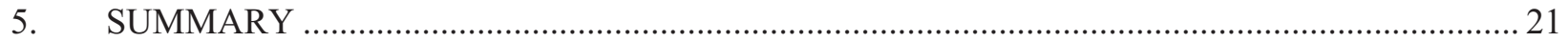

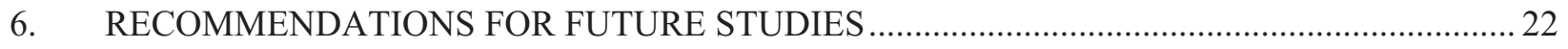

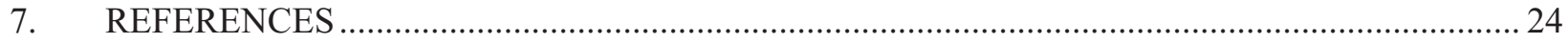

\section{FIGURES}

Figure 1. Illustration of the ATR core arrangement and irradiation positions.......................................... 3

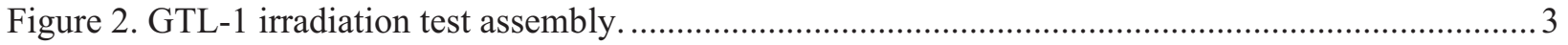

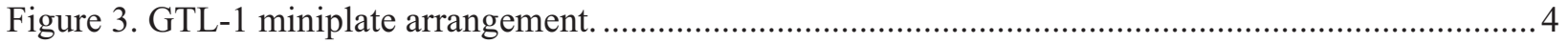

Figure 4. Cross-section of GTL-1 experiment assembly. .................................................................. 4

Figure 5. Miniplate dimensions with hydroxide measurement locations................................................. 9

Figure 6. PIE photograph of front and back surface of miniplate C2 (Robinson 2008)......................... 12

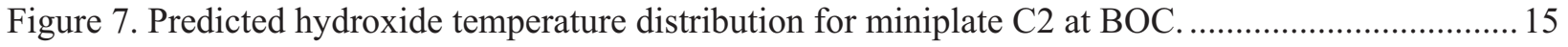

Figure 8. Average miniplate hydroxide thickness as a function of BOC peak hydroxide

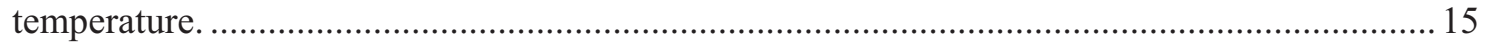

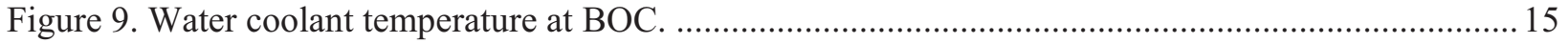

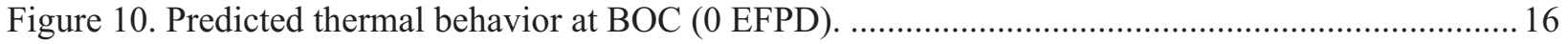

Figure 11. Predicted thermal behavior at MOC (18 EFPD)............................................................... 17

Figure 12. Predicted thermal behavior at MOC (36 EFPD) ............................................................ 18

Figure 13. Predicted thermal behavior at EOC (48.9 EFPD) .............................................................. 19 
Figure 14. Variation with irradiation time of heat flux and peak temperatures for the six hottest miniplates.

Figure 15. Variation of miniplate hydroxide heat flux with axial position.

\section{TABLES}

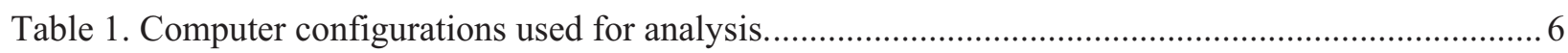

Table 2. GTL-1 experiment component drawing numbers and titles. ......................................................

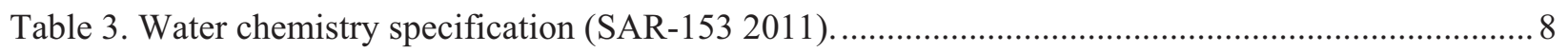

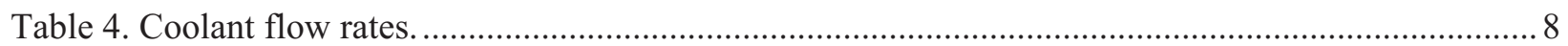

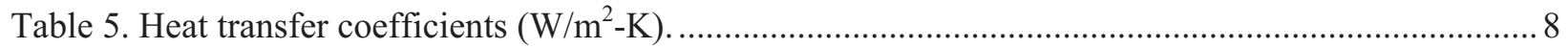

Table 6. Measured hydroxide layer thickness $(\mu \mathrm{m})$ (Robinson 2008) ...................................................... 10

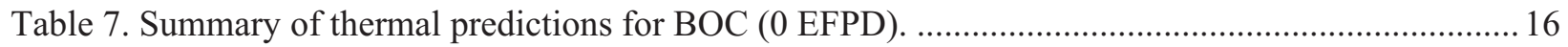

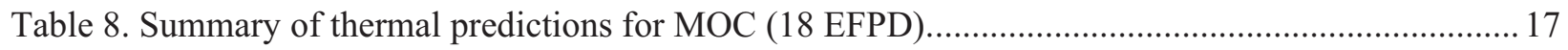

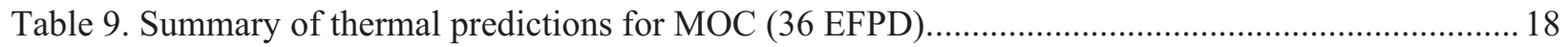

Table 10. Summary of thermal predictions for EOC (48.9 EFPD)....................................................... 19 


\section{ACRONYMS}

$\begin{array}{ll}\text { ATR } & \text { Advanced Test Reactor } \\ \text { BFFL } & \text { Boosted Fast Flux Loop } \\ \text { BOC } & \text { beginning of cycle } \\ \text { ECAR } & \text { Engineering Calculations and Analysis Report } \\ \text { EDF } & \text { Engineering Design File } \\ \text { EFPD } & \text { effective full power days } \\ \text { EOC } & \text { end of cycle } \\ \text { GTL } & \text { Gas Test Loop } \\ \text { INL } & \text { Idaho National Laboratory } \\ \text { IPT } & \text { inpile tube } \\ \text { MOC } & \text { middle of cycle } \\ \text { PIE } & \text { post-irradiation examination } \\ \text { RERTR } & \text { Reduced Enrichment for Research and Test Reactors } \\ \text { SFT } & \text { south flux trap }\end{array}$




\section{As-Run Thermal Analysis of the GTL-1 Experiment Irradiated in the ATR South Flux Trap}

\section{INTRODUCTION}

Gas Test Loop (GTL) irradiation experiment GTL-1 was sponsored by the U.S. Department of Energy as part of the GTL project (which later became the Boosted Fast Flux Loop [BFFL] project) to determine the feasibility of designing, constructing, and installing an experimental vehicle in an existing host irradiation facility that can replicate, with reasonable fidelity, the fast-flux test environment needed for irradiation testing of new fuels and materials. The technical and functional requirements for the BFFL stipulate a minimum neutron flux intensity $\left(10^{15} \mathrm{n} / \mathrm{cm}^{2} \cdot \mathrm{s}\right)$ and fast-to-thermal neutron ratio $(>15)$ for the test environment (Longhurst and Khericha 2005). To achieve the necessary neutron flux levels, a system comprised of booster fuel and thermal neutron filters was designed for incorporation in the northwest test lobe of the Advanced Test Reactor (ATR) at Idaho National Laboratory (INL).

The desired neutron flux characteristics led to the selection of high-density $\left(4.8 \mathrm{~g}-\mathrm{U} / \mathrm{cm}^{3}\right) \mathrm{U}_{3} \mathrm{Si}_{2} / \mathrm{Al}$ dispersion fuel plates clad with 6061 aluminum for the BFFL booster fuel. Uranium silicide dispersion fuel is an ideal choice for the booster fuel because it exhibits low parasitic neutron absorption and good irradiation and chemical stability (Bourns 1968). The U.S. Nuclear Regulatory Commission formally approved (NUREG-1313 1988) the use of $\mathrm{U}_{3} \mathrm{Si}_{2} / \mathrm{Al}$ dispersion fuel with uranium densities up to $4.8 \mathrm{~g} / \mathrm{cm}^{3}$ in domestic research and test reactors, but the new booster fuel requires demonstration because the fuel meat for the BFFL application is thicker, the radius of curvature is smaller, and the heat fluxes are higher than previous experience. In addition, experiments conducted in the Belgian Reactor 2 (BR2) reactor operated by the Belgian Nuclear Research Centre $(\mathrm{SCK} \cdot \mathrm{CEN})$ in Mol, Belgium exhibited failure of aluminum clad $\mathrm{U}_{3} \mathrm{Si}_{2} / \mathrm{Al}$ dispersion fuel plates loaded to $6.0 \mathrm{~g}-\mathrm{U} / \mathrm{cm}^{3}$ and exposed to heat fluxes on the order of $5.5 \mathrm{MW} / \mathrm{m}^{2}$ (Leenaers et al. 2004). In that instance, fuel plate failure was attributed to inadequate cooling that led to the accelerated corrosion of the AG3-NET Al-Mg alloy (nuclear grade Al-5754) cladding. Once highly corroded, the "much lower thermal conductivity of the corrosion layer $(2.25 \mathrm{~W} / \mathrm{m}$ $\mathrm{K})$ compared to AG3-NET alloy $(130 \mathrm{~W} / \mathrm{m}-\mathrm{K})$ " caused an "increase in temperature of the cladding." The "calculations show that the cladding reached temperatures in excess of $300^{\circ} \mathrm{C}$ " and "at these high temperatures, progressing sensitization of the aluminum-magnesium cladding leads to the decoration of the grain boundaries with $\mathrm{Mg}_{2} \mathrm{Al}_{3}$ precipitates, making the cladding susceptible to grain boundary corrosion" (Leenaers et al. 2004).

To avoid potential runaway corrosion of the ATR driver fuel, prior to reactor operation the fuel plates are autoclaved with a water solution at a controlled temperature, pressure, and $\mathrm{pH}$ to form a stable, protective hydroxide layer (a crystalline, nonporous gamma-alumina hydrate or boehmite). Application of a very thin boehmite layer serves to passivate the cladding surface, which inhibits corrosion product buildup during irradiation and subsequent hydroxide spalling (Shaber and Hofman 2005). Prefilming the fuel cladding is an important protective measure because hydroxide layers formed in the presence of neutron radiation tend to grow much thicker, are more subject to erosion, and are less resistant to chemical attack (Byalobzheskii 1962).

There are several key differences between the BR2 plate failure and the BFFL booster fuel design. The BR2 fuel plates were not pretreated, used a cladding alloy with a different composition, and experienced different coolant chemistry and flow. The BFFL fuel plates are designed with Al-6061 cladding, which has different composition and physical properties than the AG3-NET cladding. Lack of data on prefilmed fuel plates similar in composition to the proposed BFFL booster fuel and operating under similar conditions prompted inpile tests to be conducted for representative samples of the proposed BFFL booster fuel. 
Irradiation testing of miniplates with prototypic construction was conducted at heat fluxes and coolant flow velocities typical of the booster fuel. Miniplates were exposed to peak heat fluxes up to $593 \mathrm{~W} / \mathrm{m}^{2}$ $\left(2.622 \mathrm{Btu} / \mathrm{s} \cdot \mathrm{in}^{2}\right)$, which bounds the nominal BFFL booster fuel operating heat flux levels of $450 \mathrm{~W} / \mathrm{m}^{2}$ $\left(2.75 \mathrm{Btu} / \mathrm{s} \cdot \mathrm{in}^{2}\right)$. The primary objectives of the experiment with respect to corrosion performance were to ensure that: (1) uncontrolled or unexpected hydroxide growth or change does not occur during irradiation, and (2) the corrosion/erosion processes do not compromise the structural properties and containment capabilities of the fuel cladding. Of interest to the BFFL program are the processes or conditions that contribute to keeping the hydroxide film thin, thus improving fuel performance.

This report documents as-run thermal evaluations for an inpile experiment (designated GTL-1) conducted at high heat flux for the purpose of assessing the performance of $25 \%$ enriched, high-density $\left(4.8 \mathrm{~g}-\mathrm{U} / \mathrm{cm}^{3}\right) \mathrm{U}_{3} \mathrm{Si}_{2} / \mathrm{Al}$ dispersion fuel miniplates clad with 6061 aluminum and pretreated with a stable hydroxide film. The thermal analyses performed prior to irradiation were executed for a bounding case to satisfy ATR Nuclear Safety requirements (Guillen 2008). However, to draw meaningful conclusions from the GTL-1 miniplate irradiation experiment regarding the performance of the hydroxide film on the miniplates, it is necessary to perform a thermal analysis at the actual power levels experienced during irradiation. A Monte Carlo Neutron Particle physics analysis provided as-run fuel fission heat generation rates at four times during ATR Cycle 143A for the GTL-1 fuel miniplates irradiated in the ATR south flux trap (SFT) irradiation test position as shown in Figure 1 (Perez and Chang 2010). Post-irradiation examination (PIE) measurements of hydroxide layer thickness on each of the 16 fueled miniplates (Robinson 2008) were also used in the thermal analysis. Heat flux and temperatures for the miniplate fuel, cladding, hydroxide, and coolant-hydroxide interface are presented at beginning of cycle (BOC) at 0 effective full power days (EFPD), middle of cycle (MOC) at 18 EFPD, MOC at 36 EFPD, and end of cycle (EOC) at 48.9 EFPD.

These evaluations were requested by Reduced Enrichment for Research and Test Reactors (RERTR) project staff. Recommendations for future work are provided. Such studies are necessary to gain a better understanding of the hydroxide layer formed during irradiation. 


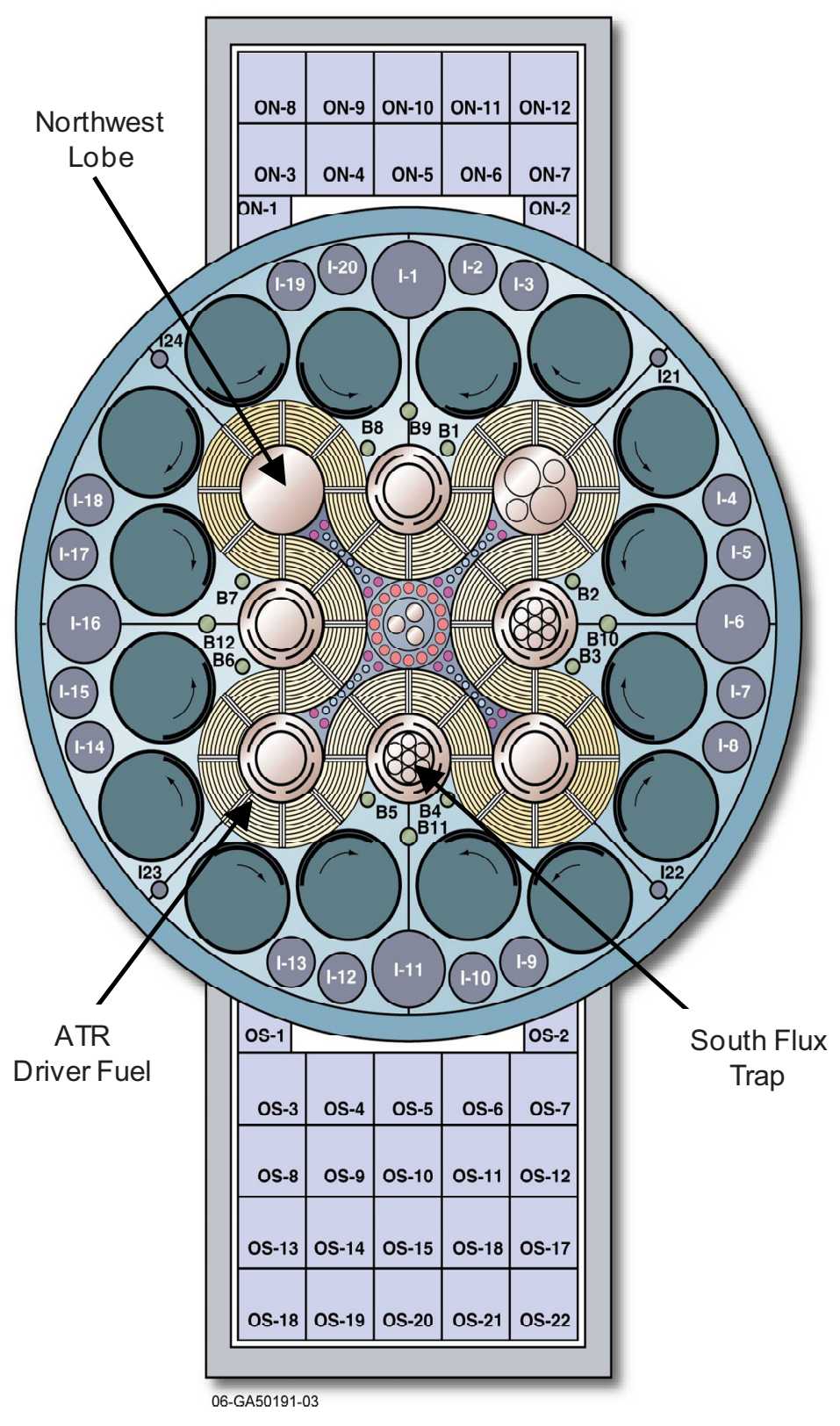

Figure 1. Illustration of the ATR core arrangement and irradiation positions.

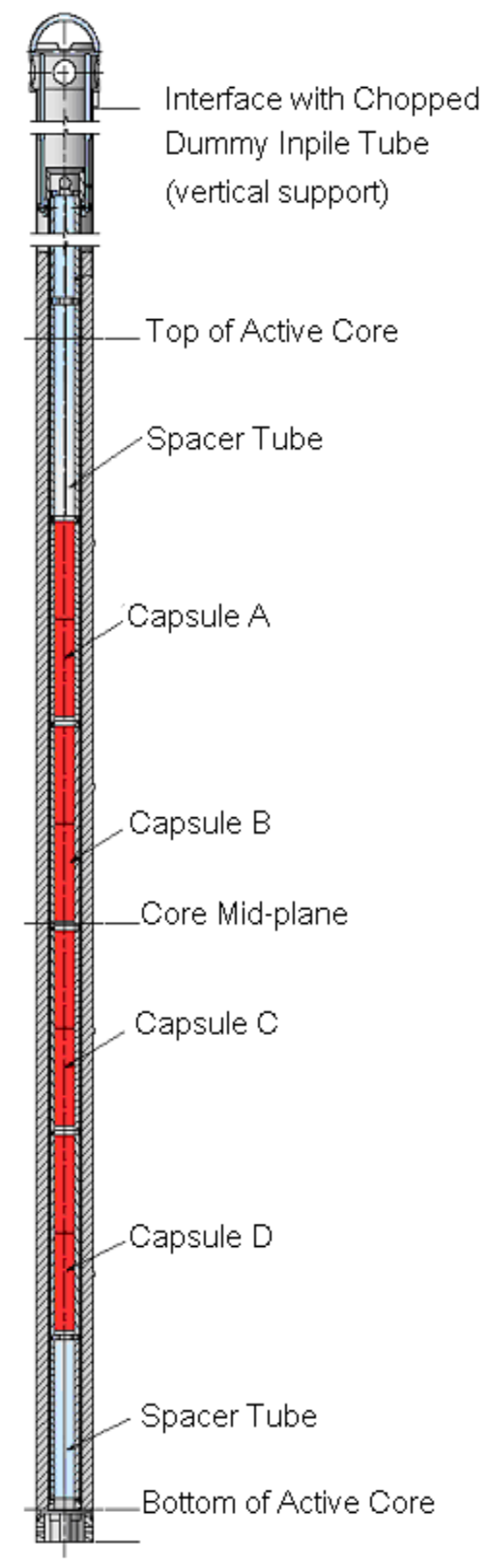

Figure 2. GTL-1 irradiation test assembly. 


\section{EXPERIMENT DESCRIPTION}

\subsection{Experiment Design}

The GTL-1 irradiation experiment contains 16 miniplates housed in four interconnecting flowthrough capsules, designated as A, B, C, and D, with A at the top of the test assembly and D at the bottom as shown in Figure 2. There are four miniplates in each capsule arranged vertically in a $2 \times 2$ array (each capsule has two axial levels, with two miniplate positions per level). Within each capsule, the miniplate positions are designated as 1 and 2 in the upper level and 3 and 4 in the lower level. Figure 3 shows the arrangement of the miniplates within the four capsules. The test matrix consisted of three different fuel fabrication variations: two miniplates without fines, one miniplate with annealed powder, and 13 with standard powder. All miniplates received a prefilming treatment. The faces of the miniplates were oriented "edge-on," such that they were parallel to a radial line from the core center through the center of the SFT position as shown in Figure 4. The miniplates are $2.5 \mathrm{~cm}$ wide and $10.2 \mathrm{~cm}$ long. The fuel meat thickness of all plates is $0.102 \mathrm{~cm}$, the cladding is $0.076 \mathrm{~cm}$ on either side of the fuel, and the total plate thickness is $0.254 \mathrm{~cm}$. These plates are referred to as "double-thick" since the fuel meat thickness is twice that of a standard materials test reactor type fuel plate. The increased thickness is necessary to produce the high heat flux levels. A 6061 aluminum border surrounds the $9.5 \times 1.83 \mathrm{~cm}$ fuel region. Inside of each capsule, the two columns of two miniplates are arranged end-to-end, with no spacing between the plates in the flow direction (the bottom end of the upper plate rests against the top end of the lower plate), measuring $20.3 \mathrm{~cm}$ long. There is a $0.98 \mathrm{~cm}$ axial separation between fuel plates in adjacent capsules (Hayes 2008).

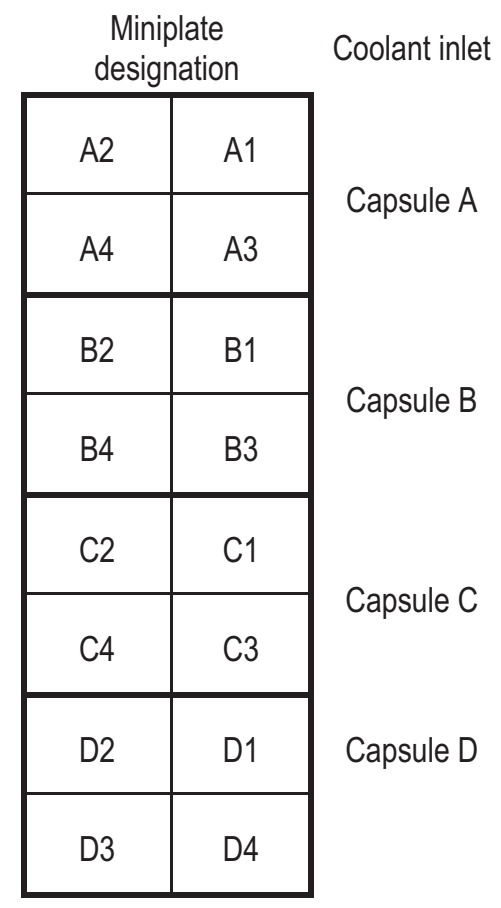

Figure 3. GTL-1 miniplate arrangement.

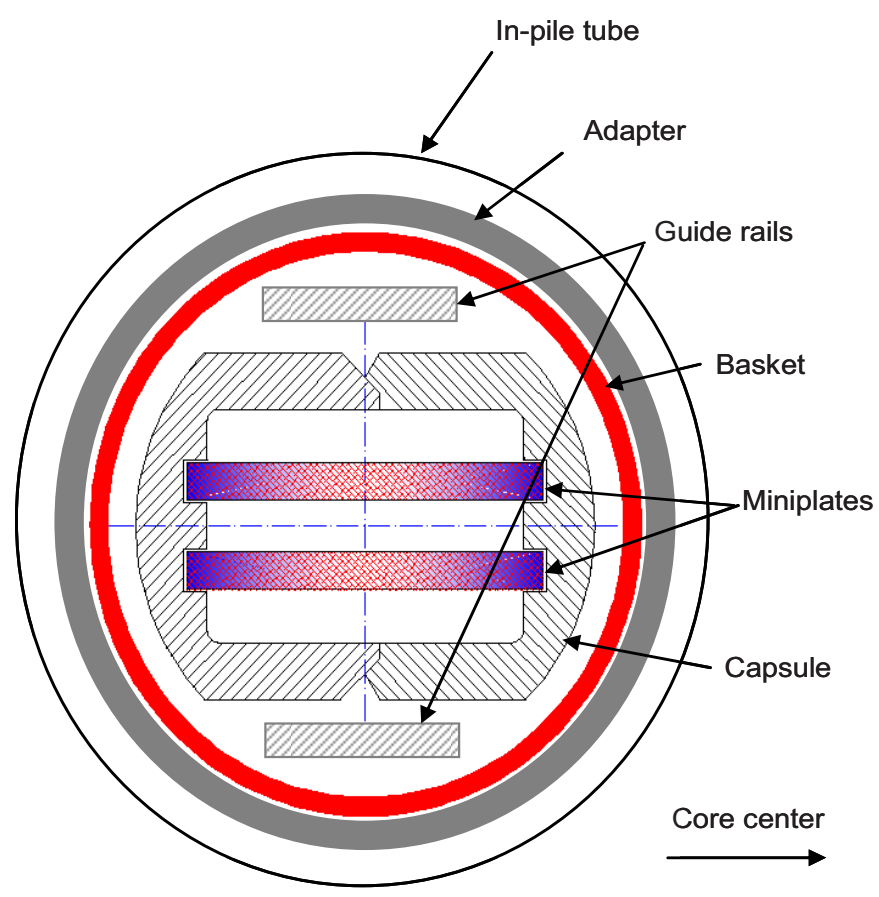

Figure 4. Cross-section of GTL-1 experiment assembly. 
The miniplates were prefilmed in an autoclave prior to irradiation to produce a uniform, adherent boehmite $\left(\mathrm{Al}_{2} \mathrm{O}_{3} \cdot \mathrm{H}_{2} \mathrm{O}\right)$ layer on the cladding surface. The treatment was performed in an autoclave vessel filled with $\mathrm{pH}$ adjusted water. The recipe for the prefilm treatment calls for autoclaving with deionized water at a temperature of $185 \pm 8^{\circ} \mathrm{C}$ and a pressure of $0.896 \pm 0.207 \mathrm{MPa}$ held for $18 \pm 1 \mathrm{hr}$ starting when the $185^{\circ} \mathrm{C}$ temperature is reached. Prior to the treatment, the plates were chemically cleaned with a heated sodium hydroxide bath and a nitric acid etch to remove surface oxides. Thirteen of the 16 miniplates were pretreated with a surface boehmite layer (nominally $2.0 \mu \mathrm{m}$ thick) formed in an autoclave using deionized water with a $\mathrm{pH}$ of 7.8. This is referred to as the "standard" prefilm treatment. The remaining three miniplates (A2, C2, and D4) were pretreated with a thinner boehmite layer (nominally $0.5 \mu \mathrm{m}$ thick) deposited using a similar procedure with water at a $\mathrm{pH}$ of 5.7. This is referred to as the "modified" prefilm treatment (Hayes 2008). The prefilm thickness was measured using SEM photos of smooth surfaces located between regions where hydroxide had formed around surface connected precipitate particles. Although the modified prefilming process had not previously been tested in the ATR, it was expected that the fuel thermal performance with the thinner insulating layer of boehmite would be better than the standard prefilm. Since the water $\mathrm{pH}$ used to produce the modified prefilm more closely matches the $\mathrm{pH}$ of the ATR primary coolant, it is expected to be more stable and resistant to growth during irradiation. A hydroxide layer that remains thin during irradiation is sought to maximize heat transfer from the fuel to the coolant. The thermal conductivity of this prefilm boehmite layer is approximated as $2.25 \mathrm{~W} / \mathrm{m}-\mathrm{K}$ over the temperature range from 394 to $505 \mathrm{~K}$, based on ex-reactor studies (Polkinghorne and Lacy 1991).

\subsection{Power History}

The miniplates in the GTL-1 experiment were irradiated in the ATR SFT position at a significant performance margin above the BFFL design condition. The BFFL booster fuel is intended to operate under relatively aggressive conditions, characterized by a thermal heat flux of $450 \mathrm{~W} / \mathrm{cm}^{2}$. The experiment was designed to expose the miniplates to heat fluxes ranging from about 400 to $600 \mathrm{~W} / \mathrm{cm}^{2}$ ( 2.44 to $3.67 \mathrm{Btu} / \mathrm{s} \cdot \mathrm{in}^{2}$ ). The higher power levels were included in the experiment to explore a margin of safety above the expected operating power level.

The power levels of the surrounding lobes affect the power in the flux trap. Based on the power history for ATR Cycle 143A, this experiment experienced an average effective south lobe source power of 25.4 MW(t) (based upon Center lobe at 24.3 MW(t), Southwest lobe at 26.9 MW(t), and Southeast lobe at 25.0 MW(t)). The reactor was brought up to full power on September 23, 2008. A scram occurred on October 16, 2008 and the reactor was restarted on November 5, 2008. Another scram occurred on November 21, 2008, caused by a problem with another experiment. The reactor was restarted on November 26, 2008, and operated through the end of the cycle, which completed on December 6, 2008. The duration of the capsule irradiation was 48.9 EFPD. 


\section{MODEL DESCRIPTION}

\subsection{Finite Element Model}

The finite element model representing the physical geometry of the miniplate experiment configuration were developed and analyzed using the computer code ABAQUS Version 6.7-3 (Dassault Systèmes 2007) on the LINUX-based computing platforms dguillen and icestorm. ABAQUS CAE was used for construction of the finite element model, and ABAQUS Standard was used to calculate steadystate temperatures and heat fluxes.

The analysis was performed on a SGI Altix ICE 8200 distributed memory cluster with 512 Intel Xeon quad core 2.66 GHz processors running SUSE Linux Enterprise Server 10. The computer configurations listed in Table 1 were used to perform the calculations reported in this report.

Table 1. Computer configurations used for analysis.

\begin{tabular}{lllllc}
\hline Software & Version & \multicolumn{1}{c}{ Computer Type } & Operating System & \multicolumn{1}{c}{ Processor } & $\begin{array}{c}\text { Computer } \\
\text { Name }\end{array}$ \\
\hline ABAQUS & $6.7-3$ & $\begin{array}{l}\text { SGI Altix ICE 8200 } \\
\text { distributed memory cluster }\end{array}$ & $\begin{array}{l}\text { SUSE Linux Enterprise } \\
\text { Server 10 }\end{array}$ & $\begin{array}{l}\text { 512 Intel Xeon quad } \\
\text { core 2.66 GHz }\end{array}$ & icestorm \\
\hline ABAQUS & $6.7-3$ & HP xw9300 Workstation & SUSE Linux 10.2 & AMD Opteron-64 & $\begin{array}{c}\text { dguillen } \\
\# 387473\end{array}$ \\
\hline
\end{tabular}

A formal quality assessment for these platforms using code Version 6.7-3 has been completed for conditions applicable to this analysis and documented in the INL Engineering Calculations and Analysis Report ECAR-131 (Murray 2008). Supporting calculations were performed using MathCad Version 14.

The finite element model geometry was constructed using a combination of shells and threedimensional solid elements (Guillen and Murray 2009). Dimensions are based upon the drawings listed in Table 2. The assembly is comprised of the miniplates, rails, capsules, spacers, basket, adapter, and coolant channels. The model includes all four capsules of the test train assembly within the active core, along with the top, upper, and bottom spacers that are used to position the capsules axially with the basket. The basket design is the same as that for the large B-position experiments. A $0.013 \mathrm{~m}$ thick adapter constructed of 6061 aluminum is used to fill the space between the outer diameter of the basket and the inner diameter of the chopped dummy inpile tube (IPT). The adapter was necessary because the experiment was originally designed to be inserted into a large B-position with a smaller diameter than the SFT. Primary coolant water flows through the test train, the $1.016 \mathrm{~mm}$ water annulus between the basket and adapter, and the $0.940 \mathrm{~mm}$ water annulus between the adapter and IPT. There are three water coolant channels approximately $0.36 \mathrm{~cm}$ thick and $2.26 \mathrm{~cm}$ wide in contact with the fuel plates. The main water channel through the test train includes the flow through the larger area of the top, upper, and bottom spacers, and also through the confluence regions at the end of Capsule $\mathrm{A}$ and beginning of Capsule B, end of Capsule B and beginning of Capsule C, and end of Capsule C and beginning of Capsule D. Small nubs on the outside diameter of the basket and adapter maintain the spacing in the adjacent water annuli. Two guide rails between the capsules and the basket serve to center the capsules radially within the basket. The total length of the portion of the assembly modeled is $1.469 \mathrm{~m}$. 
Table 2. GTL-1 experiment component drawing numbers and titles.

\begin{tabular}{ll}
\hline Drawing No. & Drawing Title \\
\hline 443027 & ATR South and East Chopped Dummy IPT Assembly \\
\hline 600310 & ATR/ATRC BFFL (GTL-1) Miniplate Adapter Assemblies \\
\hline 600418 & ATR/ATRC BFFL (GTL-1) Miniplate SFT Adapter Back-up Assemblies \\
\hline 600420 & ATR BFFL (GTL-1) Miniplate Inner Basket Lift Assemblies and Details \\
\hline 600447 & ATR/ATRC BFFL (GTL-1) Miniplate Modified Large B-Position Basket Detail \\
\hline 600448 & ATR BFFL (GTL-1) Miniplate Irradiation Assembly \\
\hline 600450 & ATRC BFFL (GTL-1) Miniplate Irradiation Assembly \\
\hline 637209 & GTL Experiment Assembly \\
\hline 630231 & ATR Large B-Position Basket \\
\hline 630225 & ATR Top Spacer Assembly \\
\hline 630229 & ATR Upper Spacer Assembly \\
\hline 637210 & ATR Bottom Spacer Assembly \\
\hline 637212 & GTL Mini-Plate Capsule Assembly \\
\hline 637213 & Capsule, GTL \\
\hline 637215 & Capsule, Cap \\
\hline
\end{tabular}

\subsection{Thermal Hydraulic Analysis}

The ATR is cooled by pressurized (2.5 MPa) water at a pH between 4.8 and 6.0 (SAR-153 2011). During ATR Cycle 143A, the coolant $\mathrm{pH}$ remained above 5.01 with an average $\mathrm{pH}$ of approximately 5.25 (Beckwith 2011). The water chemistry specification is listed in Table 3. Coolant flow enters the experiment assembly from the top of the reactor with an inlet temperature of $52^{\circ} \mathrm{C}$. Flowing water travels downward through the test train, the annulus between the basket and the adapter, and the annulus between the adapter and the IPT. Table 4 lists the flow rates in the water channels. The loss coefficients through the test train were obtained from a hydraulic flow test (Wachs 2006). Using the experimentally-derived loss coefficients, the resulting flow velocity across the miniplates is $14.6 \mathrm{~m} / \mathrm{s}$. The velocity of cooling water flowing through the annular gaps was computed from a hydraulic analysis employing the extended Bernoulli equation (Incropera and DeWitt 2002) with the inlet conditions $\left(52^{\circ} \mathrm{C}\right.$ and $\left.2.5 \mathrm{MPa}\right)$ and pressure drop $(0.53 \mathrm{MPa})$ for two primary coolant pump operation. The calculated flow velocity is 5.1 $\mathrm{m} / \mathrm{s}$ in the annular gap between the adapter and the IPT and $7.8 \mathrm{~m} / \mathrm{s}$ in the annular gap between the adapter and the basket. The calculated total flow through the entire experiment assembly is $5.438 \times 10^{-3}$ $\mathrm{m}^{3} / \mathrm{s}$. Heat transfer coefficients for turbulent forced convection to the cooling water (shown in Table 5) were obtained from the Colburn correlation using the film temperature method to account for fluid property variation (Perry and Green 1997). Thermophysical properties used for the materials comprising the miniplates are listed in the Appendix. 
Table 3. Water chemistry specification (SAR-153 2011).

\begin{tabular}{ll}
\hline Parameter & Limits \\
\hline Conductivity, reactor power $>3 \mathrm{MW}$ & $2-5 \mu \mathrm{mhos} / \mathrm{cm}$ \\
\hline Conductivity, reactor power $<3 \mathrm{MW}$ & $2-8 \mu \mathrm{mhos} / \mathrm{cm}$ \\
\hline $\mathrm{pH}$, Reactor power $>3 \mathrm{MW}$ & $4.8-5.4$ \\
\hline $\mathrm{pH}$, Reactor power $<3 \mathrm{MW}$ & $4.8-6.0$ \\
\hline $\begin{array}{l}\text { Filterable solids }(0.45-20 \mu \mathrm{m}) \text { before exceeding } 3 \mathrm{MW} \\
\text { and during operation }\end{array}$ & $<0.02-0.08 \mathrm{ppm}$ \\
\hline Filterable solids $(>20 \mu \mathrm{m})$ & $0.025-0.05 \mathrm{ppm}$ \\
\hline Chloride & $<0.025 \mathrm{ppm}$ \\
\hline Radioactivity & $0.05-0.29 \mu \mathrm{Ci} / \mathrm{mL}$ (gross $/$ gamma based on 10 min decay \\
& after sampling) \\
\hline Dissolved aluminum & $1.5-4 \mathrm{ppb}$ \\
\hline Dissolved iron & $0.5-2 \mathrm{ppb}$ \\
\hline Dissolved copper & $0.2-1 \mathrm{ppb}$ \\
\hline
\end{tabular}

Table 4. Coolant flow rates.

\begin{tabular}{cccc}
\hline Location & Velocity & Flow Rate & Mass Flux \\
\hline Outer annulus between adapter and IPT & $5.1 \mathrm{~m} / \mathrm{s}$ & $9.93 \times 10^{-4} \mathrm{~m}^{3} / \mathrm{s}$ & $5.06 \times 10^{3} \mathrm{~kg} / \mathrm{m}^{2}-\mathrm{s}$ \\
\hline Inner annulus between basket and adapter & $7.8 \mathrm{~m} / \mathrm{s}$ & $9.39 \times 10^{-4} \mathrm{~m}^{3} / \mathrm{s}$ & $7.23 \times 10^{3} \mathrm{~kg} / \mathrm{m}^{2}-\mathrm{s}$ \\
\hline Flow across miniplates & $14.6 \mathrm{~m} / \mathrm{s}$ & $3.51 \times 10^{-3} \mathrm{~m}^{3} / \mathrm{s}$ & $1.44 \times 10^{4} \mathrm{~kg} / \mathrm{m}^{2}-\mathrm{s}$ \\
\hline Spacers/Confluence region & $9.9 \mathrm{~m} / \mathrm{s}$ & $3.51 \times 10^{-3} \mathrm{~m}^{3} / \mathrm{s}$ & $9.74 \times 10^{3} \mathrm{~kg} / \mathrm{m}^{2}-\mathrm{s}$ \\
\hline
\end{tabular}

Table 5. Heat transfer coefficients $\left(\mathrm{W} / \mathrm{m}^{2}-\mathrm{K}\right)$.

\begin{tabular}{clccc}
\hline Temperature (K) & Miniplates & Spacers & Inner annulus & Outer annulus \\
\hline 325 & $5.091 \times 10^{4}$ & $2.985 \times 10^{4}$ & $3.861 \times 10^{4}$ & $2.798 \times 10^{4}$ \\
\hline 349 & $6.517 \times 10^{4}$ & $3.820 \times 10^{4}$ & $4.941 \times 10^{4}$ & $3.582 \times 10^{4}$ \\
\hline 399 & $8.291 \times 10^{4}$ & $4.861 \times 10^{4}$ & $6.287 \times 10^{4}$ & $4.557 \times 10^{4}$ \\
\hline
\end{tabular}

Stagnant water is assumed to be trapped in the small gaps where the edges of the fuel miniplates fit into the capsules and the region surrounding the rails between the outside of the capsules and the inside of the basket. A gap conductance model was used to estimate heat transfer coefficient in stagnant regions.

\subsection{Neutronics Data}

The results of the as-run Monte Carlo N-Particle Transport Code (MCNP) neutronic analysis performed for GTL-1 experiment during ATR Cycle 143A are documented in ECAR-1350 (Perez and Chang 2010). The MCNP input model for the GTL-1 fuel mini-plates used as-built fuel volumes, masses and densities. Heat loads were provided at four times during the cycle: BOC at 0 EFPD, MOC at 18 EFPD, MOC at 36 EFPD, and EOC at 48.9 EFPD. For the thermal analysis, the average power densities were multiplied by local to average gradients over the $8.635 \times 1.829 \mathrm{~cm}$ fuel zone on each miniplate. The highest heat loads are located along the longitudinal edges of the fuel, therefore the finite-element mesh was refined there. Neutron flux in the ATR varies by position in the reactor and along the vertical length of the test position. Over the active core length, the heat flux magnitude varies with axial position relative to the core midplane where heat flux is highest.

\subsection{Hydroxide Layer Measurements}

After the experiment was removed from the reactor, post-irradiation measurements of hydroxide thickness on the miniplates were made in the hot cell at the INL Materials and Fuels Complex (Robinson 
2008). Hydroxide thickness was measured using a handheld eddy current probe manufactured by Helmut Fischer DeltaScope MP30 modified for hot cell use. Instrument uncertainty is $\pm 0.5 \mu \mathrm{m}$ when the substrate is flat, the hydroxide layer uniform, and the probe perpendicular to the miniplate surface. Hydroxide thickness was measured in nine locations on both the front and back of each miniplate for a total of 18 measurements per miniplate. The measurement locations are shown in Figure 5 where Plane B is along the longitudinal centerline and Planes $\mathrm{A}$ and $\mathrm{C}$ are $0.635 \mathrm{~cm}$ from the centerline. Plane $\mathrm{A}$ is located near the edge that was farthest from the core. Planes 1, 2, and 3 are $3.175 \mathrm{~cm}, 5.24 \mathrm{~cm}$, and $7.305 \mathrm{~cm}$ from the top of the miniplate, respectively. Values of hydroxide thicknesses at these measurement locations are tabulated in Table 6, along with a calculated average hydroxide thickness for each miniplate. The hydroxide layer on each miniplate is modeled as having a uniform thickness, given by the average value, which differs from miniplate to miniplate.

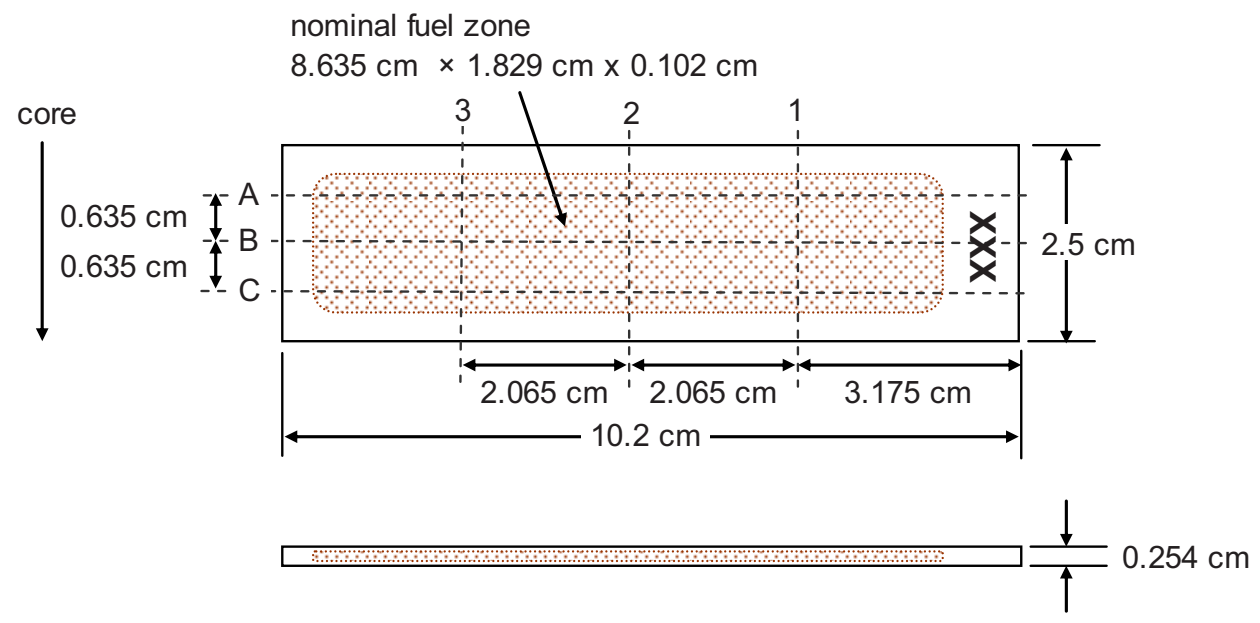

Figure 5. Miniplate dimensions with hydroxide measurement locations.

The miniplates near the core midplane exhibit the thickest hydroxide layers. The average of the measured hydroxide thickness values is the largest for Miniplates B3, B4, C1, C2, C3, and C4. The hydroxide thickness is somewhat uneven over the surface of the miniplates, with the minimum to maximum thickness varying by a factor of 2.5 to 4.5 for these six miniplates. Surface roughness on the cladding and the presence of the hydroxide layer growing around surface connected precipitates in the aluminum cladding can affect the eddy current measurements. A typical cladding surface finish prior to irradiation is $1.6 \mu \mathrm{m}$ (Guillen and Yoder 2003). The peak hydroxide thickness measured is $33 \mu \mathrm{m}$ at a point at the intersection of Plane 2 and Plane $\mathrm{C}$ on the back side of Miniplate C2, located in one of the highest power positions in the experiment. The average miniplate hydroxide thickness varies from a minimum of $1.7 \mu \mathrm{m}$ on Miniplate A2 to a maximum of $21.3 \mu \mathrm{m}$ on Miniplate $\mathrm{C} 3$. The average hydroxide thickness for all of the miniplates in the experiment is $12.8 \mu \mathrm{m}$. The thickest hydroxide measurement typically occurs along Plane 2. The standard deviation of the hydroxide measurements is larger for the miniplates closest to the core midplane, since there is more variability in the data from the mean value for those miniplates. Photographs of the front and back of Miniplate $\mathrm{C} 2$ taken during the visual examination of the GTL-1 miniplates are shown in Figure 6 (Robinson 2008). The contrast between lighter and darker tones along the surface of the miniplate is probably due to variations in the hydroxide composition and/or texture. Such discoloration in the heated zone is not seen on ATR driver fuel plates (Shaber 2009). The hydroxide layers showed no evidence of spalling. Miniplates fabricated with three different fuel variations (without fines, annealed, and with standard powder) performed equally well. PIE showed that irradiationinduced swelling was negligible and the fuel exhibited a normal fission density gradient (Robinson 2008). 
Table 6. Measured hydroxide layer thickness ( $\mu \mathrm{m})$ (Robinson 2008).

\begin{tabular}{|c|c|c|c|c|c|c|c|c|c|c|}
\hline Capsule & Miniplate & Variation & Plane & Front-A & Front-B & Front-C & Back-A & Back-B & Back-C & Average \& Std. Dev \\
\hline \multirow{13}{*}{ A } & \multirow{3}{*}{ A1 } & \multirow{3}{*}{$\begin{array}{l}\text { Std. prefilm } \\
\text { Std. powder }\end{array}$} & 1 & 0.4 & 2.3 & 1.7 & 2.4 & 1.6 & 2.9 & \multirow{3}{*}{$3.1 \pm 1.368$} \\
\hline & & & 2 & 1.5 & 3.6 & 5.3 & 3.5 & 4.0 & 5.0 & \\
\hline & & & 3 & 1.8 & 3.8 & 4.0 & 4.7 & 3.5 & 4.2 & \\
\hline & \multirow{3}{*}{ A2 } & \multirow{3}{*}{$\begin{array}{l}\text { Mod. Prefilm } \\
\text { Std. powder }\end{array}$} & 1 & 1.3 & 2.6 & 2.5 & 0.9 & 2.1 & 1.9 & \multirow{3}{*}{$1.7 \pm 0.950$} \\
\hline & & & 2 & 1.7 & 3.4 & 2.8 & 1.4 & 1.6 & 3.2 & \\
\hline & & & 3 & 1.5 & 0.6 & 0.9 & 0.1 & 0.6 & 0.8 & \\
\hline & & & & & & & & & & \\
\hline & \multirow{3}{*}{ A3 } & \multirow{3}{*}{$\begin{array}{l}\text { Std. prefilm } \\
\text { Std. powder }\end{array}$} & 1 & 8.8 & 8.2 & 12.3 & 5.2 & 8.7 & 7.1 & \multirow{3}{*}{$10.4 \pm 2.636$} \\
\hline & & & 2 & 10.1 & 14.1 & 15.9 & 9.5 & 12.4 & 12.8 & \\
\hline & & & 3 & 9.1 & 10.3 & 9.5 & 9.5 & 10.4 & 13.3 & \\
\hline & \multirow{3}{*}{ A4 } & \multirow{3}{*}{$\begin{array}{l}\text { Std. prefilm } \\
\text { Std. powder }\end{array}$} & 1 & 3.2 & 5.0 & 7.5 & 3.2 & 3.1 & 5.1 & \multirow{3}{*}{$6.8 \pm 2.580$} \\
\hline & & & 2 & 8.7 & 8.1 & 12.0 & 8.0 & 7.7 & 10.3 & \\
\hline & & & 3 & 5.6 & 5.4 & 7.4 & 5.0 & 6.4 & 10.4 & \\
\hline
\end{tabular}

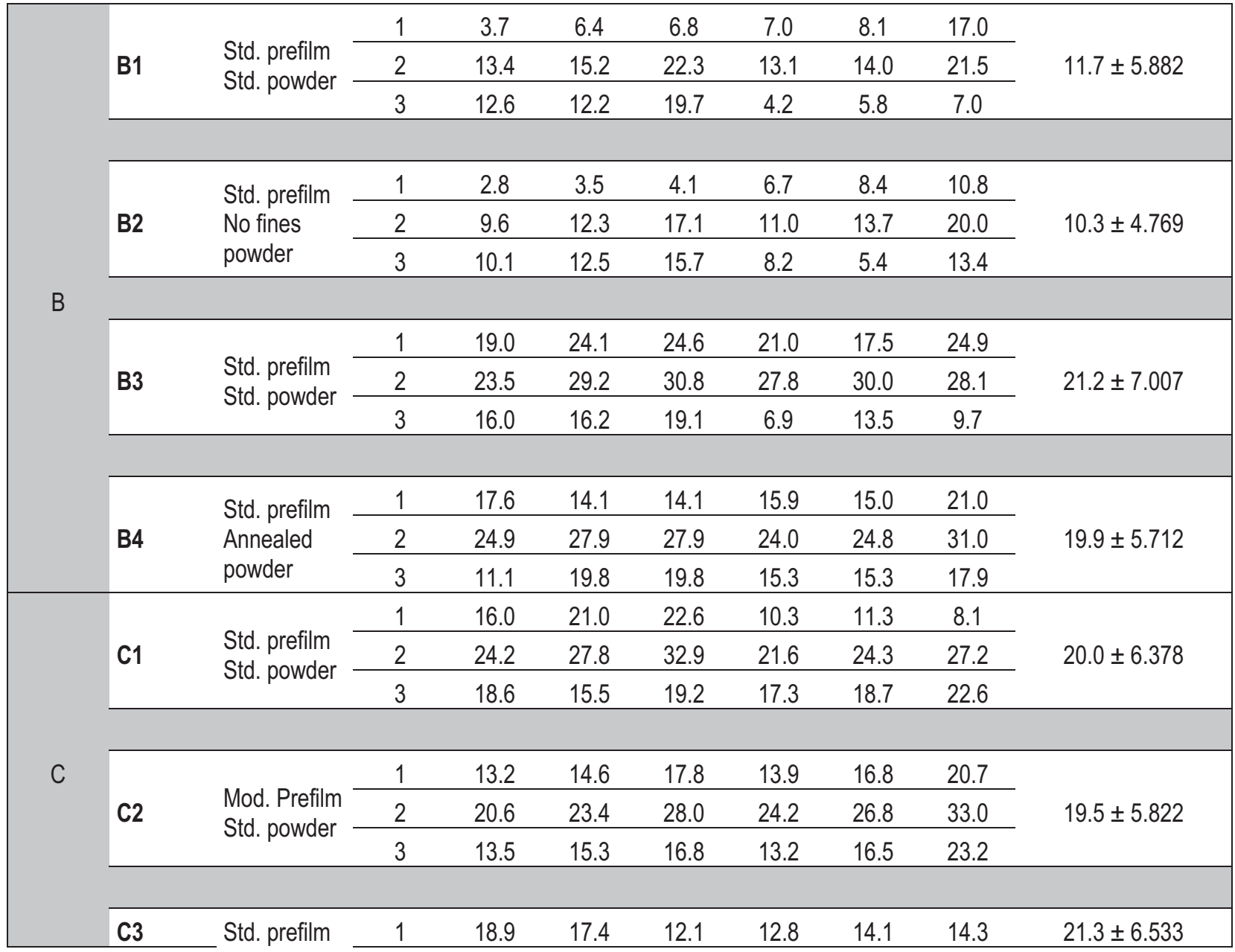




\begin{tabular}{|c|c|c|c|c|c|c|c|c|c|c|}
\hline Capsule & Miniplate & Variation & Plane & Front-A & Front-B & Front-C & Back-A & Back-B & Back-C & Average \& Std. Dev. \\
\hline & & \multirow[t]{2}{*}{ Std. powder } & 2 & 30.0 & 29.5 & 28.4 & 29.7 & 29.0 & 29.6 & \\
\hline & & & 3 & 17.4 & 18.3 & 20.7 & 17.0 & 24.2 & 19.5 & \\
\hline & \multirow{3}{*}{ C4 } & \multirow{3}{*}{$\begin{array}{l}\text { Std. prefilm } \\
\text { Std. powder }\end{array}$} & 1 & 10.1 & 10.7 & 9.8 & 20.7 & 16.4 & 20.8 & \multirow{3}{*}{$20.8 \pm 6.539$} \\
\hline & & & 2 & 27.2 & 25.3 & 26.4 & 27.6 & 32.7 & 27.0 & \\
\hline & & & 3 & 23.2 & 21.0 & 22.2 & 17.2 & 20.3 & 15.3 & \\
\hline
\end{tabular}

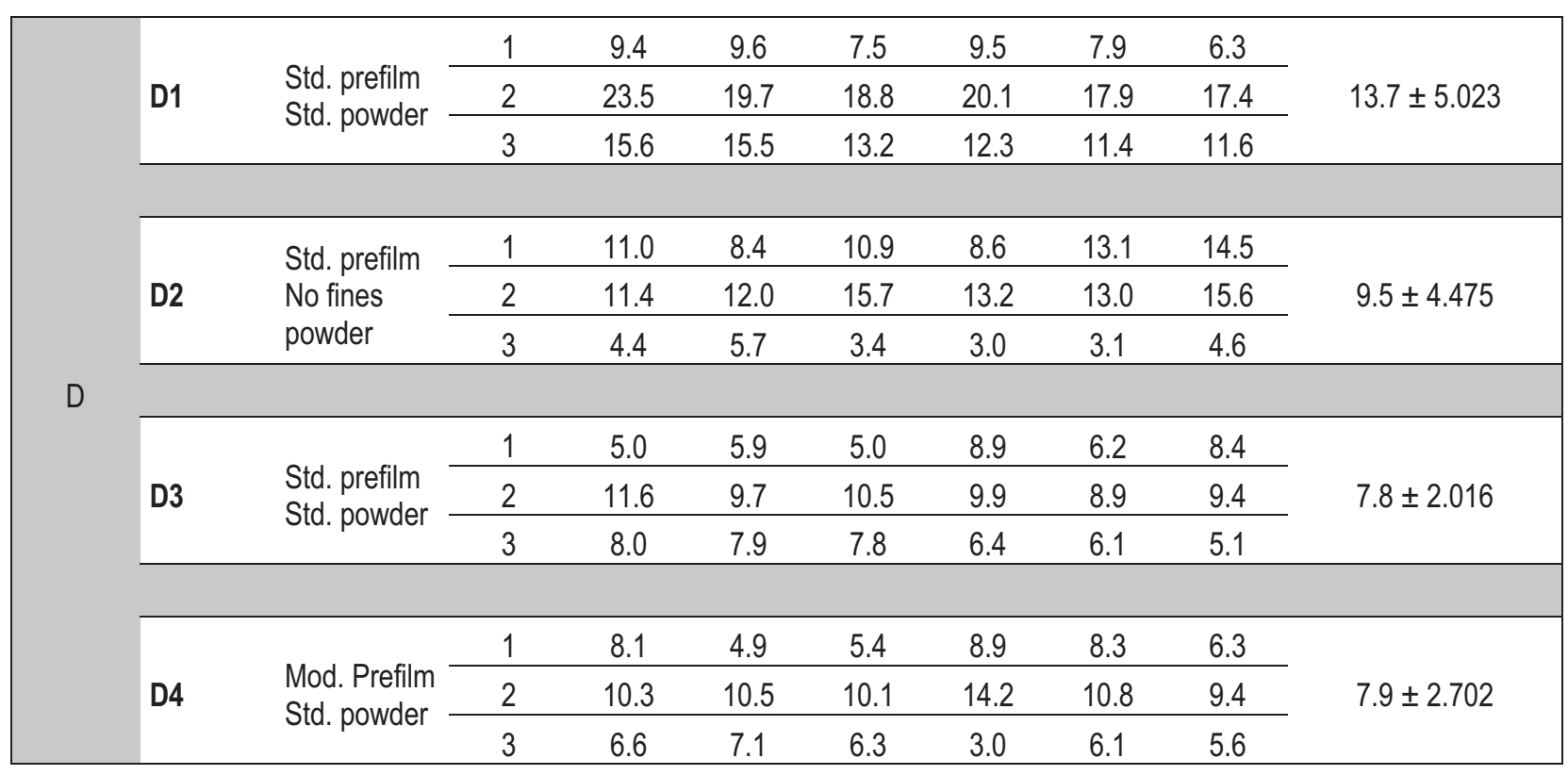




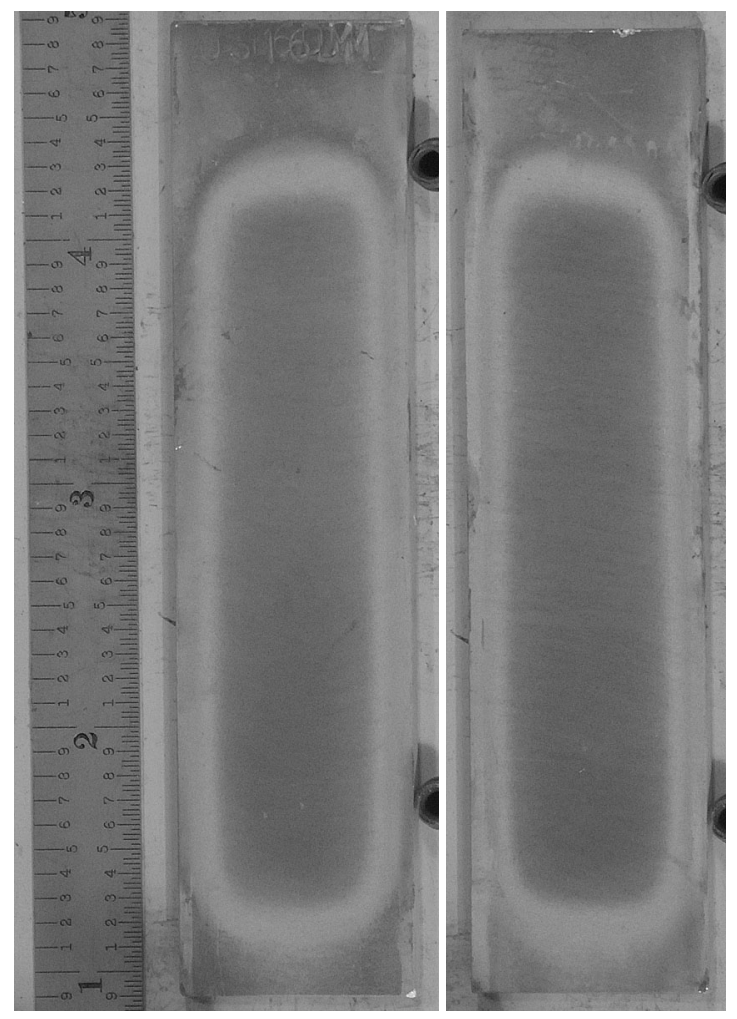

Figure 6. PIE photograph of front and back surface of miniplate $C 2$ (Robinson 2008). 


\section{RESULTS AND DISCUSSION}

Figure 7 shows the predicted hydroxide temperature distribution for miniplate $\mathrm{C} 2$ at $\mathrm{BOC}$. The contour plots show that the hottest regions of the miniplates are in the fueled zone, whereas relatively cooler temperatures are found in the aluminum border surrounding the fuel.

Figure 8 shows the variation of average hydroxide thickness as a function of calculated peak hydroxide temperature at BOC. The average hydroxide thickness increases monotonically with hydroxide temperature to a maximum value of $21.3 \mu \mathrm{m}$ at a temperature of $194^{\circ} \mathrm{C}$. This increase in measured hydroxide layer thickness at higher temperatures could be due to irregularities in surface texture and is an area where further PIE is needed. The data for the 16 miniplates appear to be clustered into three groupings at low, mid and high hydroxide temperature. The data for the six hottest miniplates are clustered at the upper right of this figure.

Figure 9 shows the predicted coolant temperature for the water channels in contact with the miniplates. In this figure, the coolant enters from the top right and flows downward towards the left. The coolant in the center coolant channel heats up more than that in the outer channels. The water heats up from an inlet temperature of $52^{\circ} \mathrm{C}$ to a maximum of $73^{\circ} \mathrm{C}$ at the outlet of Capsule D.

Results of the thermal analysis are given in a graphical (Figures 10 to 13) and tabulated (Tables 5 through 8) format at four times during the cycle: BOC at 0 EFPD, MOC at 18 EFPD, MOC at 36 EFPD, and EOC at 48.9 EFPD. The highest temperatures and heat fluxes occur at the BOC and decrease in a linear manner throughout the cycle as shown in Figure 14.

For each of the four times during the cycle, predicted peak heat flux and temperatures are given for all 16 miniplates. The "peak" value listed is the highest reported value of all nodes on the miniplate. Figures 10 to 13 show the relative magnitudes of peak fuel, cladding, hydroxide, and hydroxide-water interface temperature.

Tables 7 through 10 reveal that the predicted fuel centerline temperatures are well below the steadystate operating temperature limit of $450^{\circ} \mathrm{C}$ for all miniplates (Hayes 2006). The maximum hydroxide temperature is $194^{\circ} \mathrm{C}$. The hydroxide layer is the thickest on miniplates B3, B4, C1, C2, C3, and C4. There is a sharp increase in hydroxide layer thickness for these plates, as compared to the other plates in the experiment. The hydroxide layer thickness averages $20.4 \mu \mathrm{m}$ for the six hottest miniplates. The predicted peak hydroxide temperature on these six miniplates exceeds the prefilm application temperature of $185^{\circ} \mathrm{C}$. These miniplates are located close to the core midplane and consequently exhibit the highest peak hydroxide heat flux and peak centerline fuel and hydroxide layer temperatures. Figure 15 shows the variation of miniplate hydroxide heat flux with axial position. The high heating near the core midplane is due to the cosine-shaped axial power profile in the reactor. The coolant heats up as it travels downwards through the test train and is less effective at removing heat from the miniplates. Calculated peak hydroxide heat flux levels for these six hottest miniplates range from 565 to $593 \mathrm{~W} / \mathrm{cm}^{2}$ and calculated peak steady-state fuel centerline temperatures range from 302 to $308^{\circ} \mathrm{C}$. The six miniplates with the thickest hydroxide layer have the following thermal characteristics at BOC:

- Peak fuel centerline temperature ranges from 302 to $308^{\circ} \mathrm{C}$

- Peak cladding temperature ranges from 218 to $221^{\circ} \mathrm{C}$

- Peak hydroxide temperature ranges from 193 to $196^{\circ} \mathrm{C}$

- Peak hydroxide-water interface temperature ranges from 141 to $142^{\circ} \mathrm{C}$

- Peak heat flux ranges from 565 to $593 \mathrm{~W} / \mathrm{cm}^{2}$. 
The peak hydroxide temperature occurs at the metal-oxide interface, where the hydroxide layer is in direct contact with the cladding. The peak hydroxide-water interface temperature given in Tables 7 through 10 is the temperature at the hydroxide surface in contact with the coolant water. At the hottest location on miniplate $\mathrm{C} 2$, there is a $51^{\circ} \mathrm{C}$ temperature gradient across the hydroxide layer. Due to lack of data on actual hydroxide layer growth kinetics, these results conservatively assume that the hydroxide layer thickness on the miniplates at the four time steps was that measured after irradiation. The computational results indicate that fuel centerline temperature increases by approximately $2.25^{\circ} \mathrm{C}$ per $\mu \mathrm{m}$ of hydroxide thickness. 

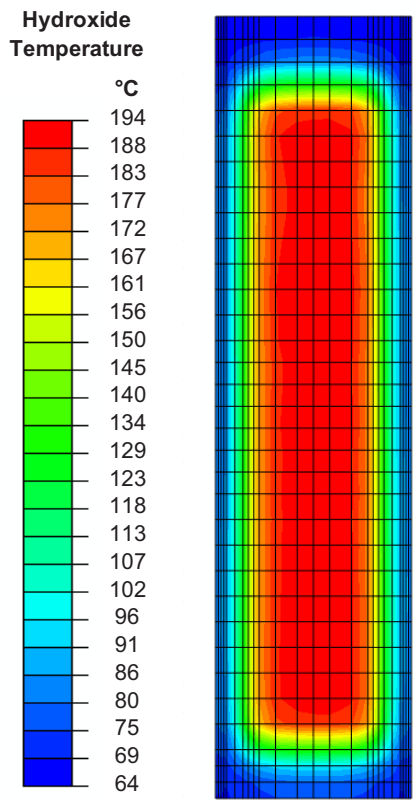

Figure 7. Predicted hydroxide temperature distribution for miniplate $\mathrm{C} 2$ at BOC.

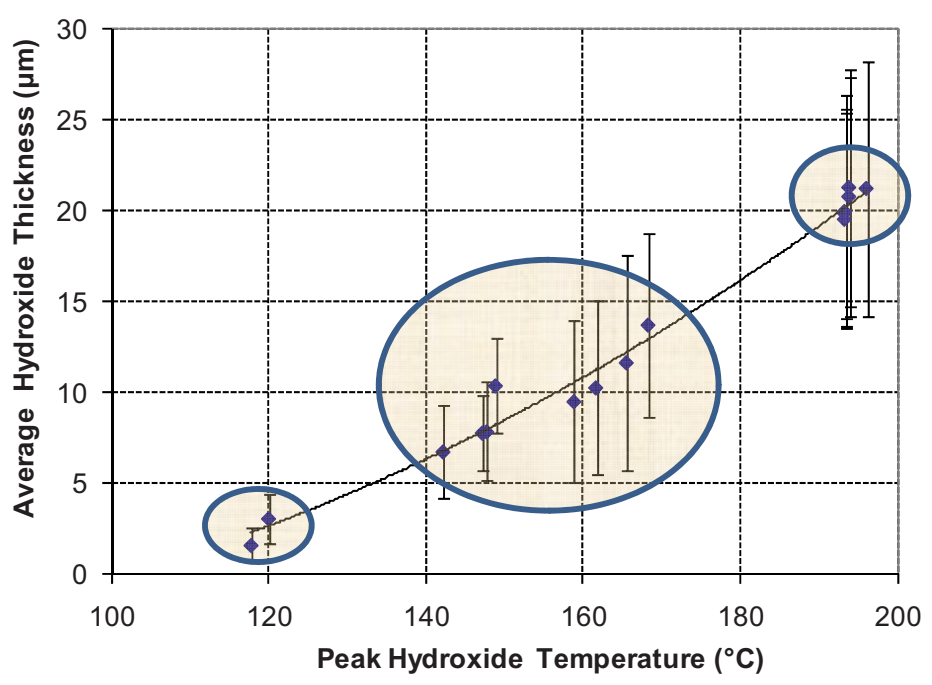

Figure 8. Average miniplate hydroxide thickness as a function of $\mathrm{BOC}$ peak hydroxide temperature.

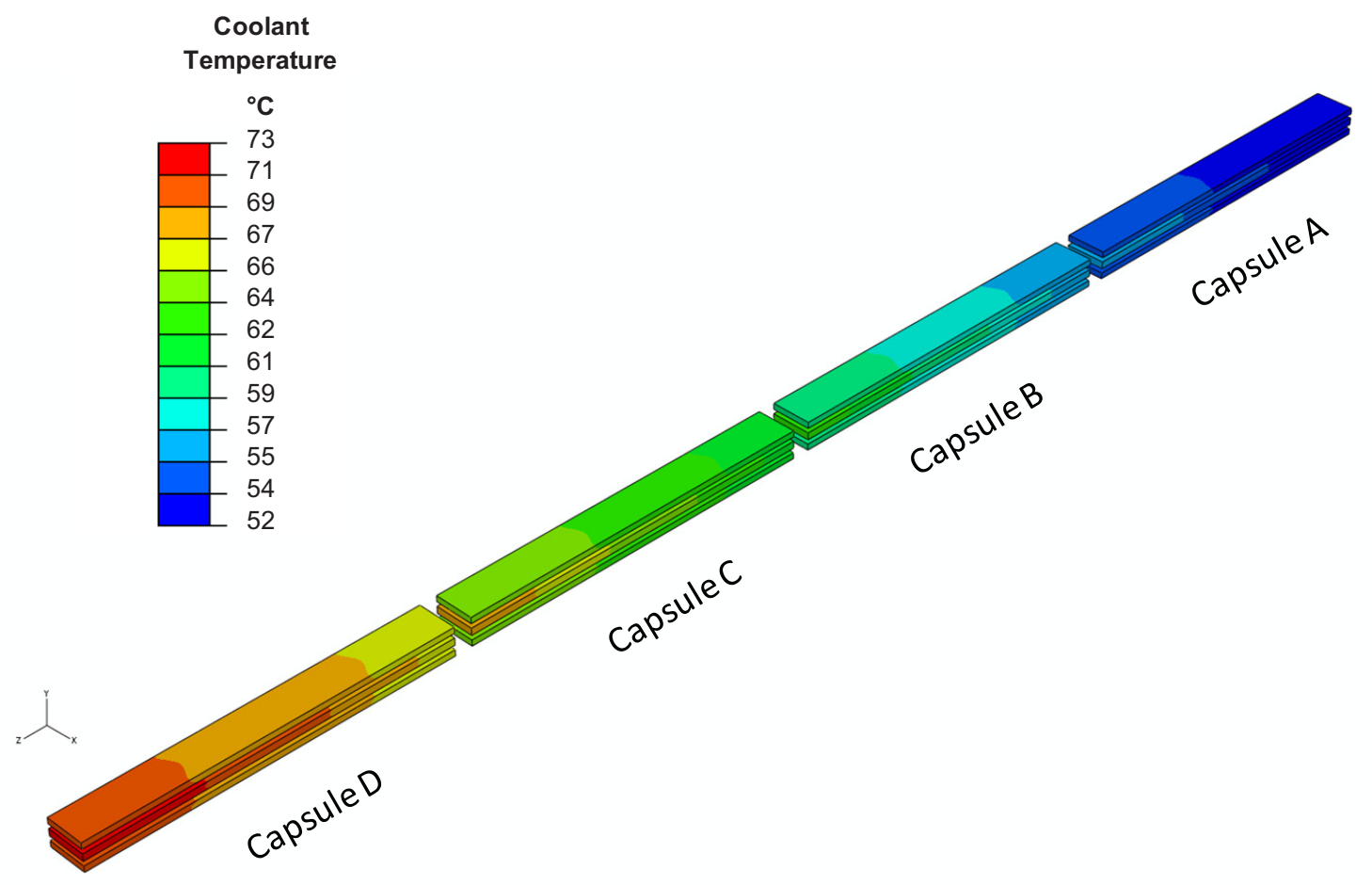

Figure 9. Water coolant temperature at BOC. 


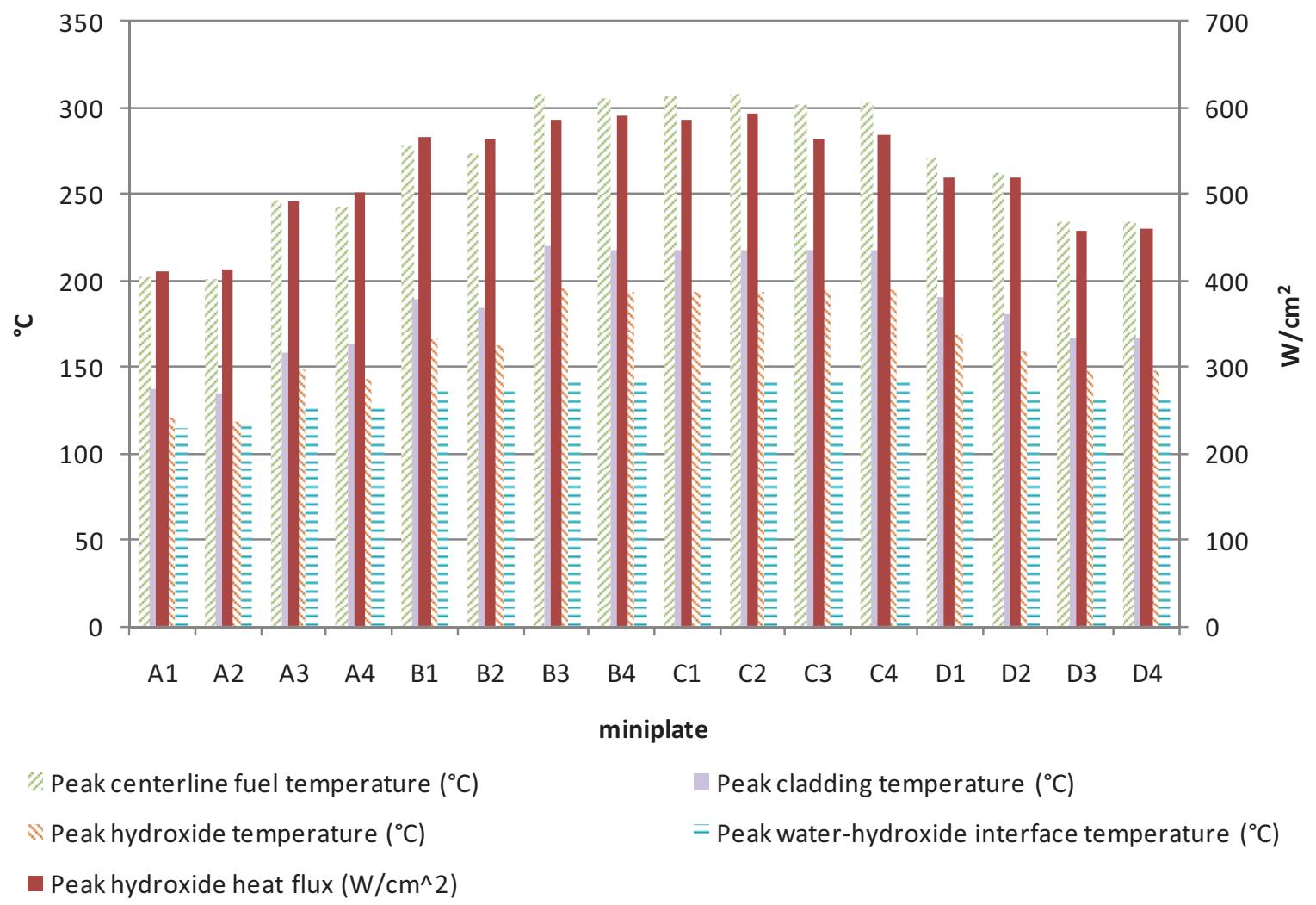

Figure 10. Predicted thermal behavior at BOC (0 EFPD).

Table 7. Summary of thermal predictions for BOC (0 EFPD).

\begin{tabular}{|c|c|c|c|c|c|}
\hline \multirow{2}{*}{ Plate } & $\begin{array}{c}\text { Peak Hydroxide } \\
\text { Heat Flux }\end{array}$ & $\begin{array}{c}\text { Peak Centerline } \\
\text { Fuel Temperature }\end{array}$ & $\begin{array}{c}\text { Peak Cladding } \\
\text { Temperature }\end{array}$ & $\begin{array}{c}\text { Peak Hydroxide } \\
\text { Temperature }\end{array}$ & $\begin{array}{c}\text { Peak Water- } \\
\text { Hydroxide Interface } \\
\text { Temperature }\end{array}$ \\
\cline { 2 - 6 } & $\mathbf{W} / \mathbf{c m}^{\mathbf{2}}$ & ${ }^{\circ} \mathbf{C}$ & ${ }^{\circ} \mathbf{C}$ & ${ }^{\circ} \mathbf{C}$ & 114 \\
\hline A1 & 411 & 202 & 137 & 120 & 118 \\
\hline A2 & 414 & 200 & 135 & 149 & 126 \\
\hline A3 & 493 & 247 & 159 & 142 & 127 \\
\hline B1 & 502 & 242 & 163 & 166 & 137 \\
\hline B2 & 567 & 278 & 189 & 162 & 136 \\
\hline B3 & 564 & 274 & 185 & 196 & 141 \\
\hline B4 & 587 & 308 & 221 & 193 & 141 \\
\hline C1 & 590 & 306 & 218 & 193 & 142 \\
\hline C2 & 593 & 307 & 218 & 194 & 142 \\
\hline C3 & 565 & 308 & 218 & 194 & 142 \\
\hline C4 & 570 & 302 & 218 & 194 & 137 \\
\hline D1 & 520 & 303 & 218 & 168 & 137 \\
\hline D2 & 520 & 271 & 191 & 159 & 132 \\
\hline D3 & 457 & 262 & 181 & 147 & 132 \\
\hline D4 & 459 & 233 & 167 & 148 & \\
\hline
\end{tabular}




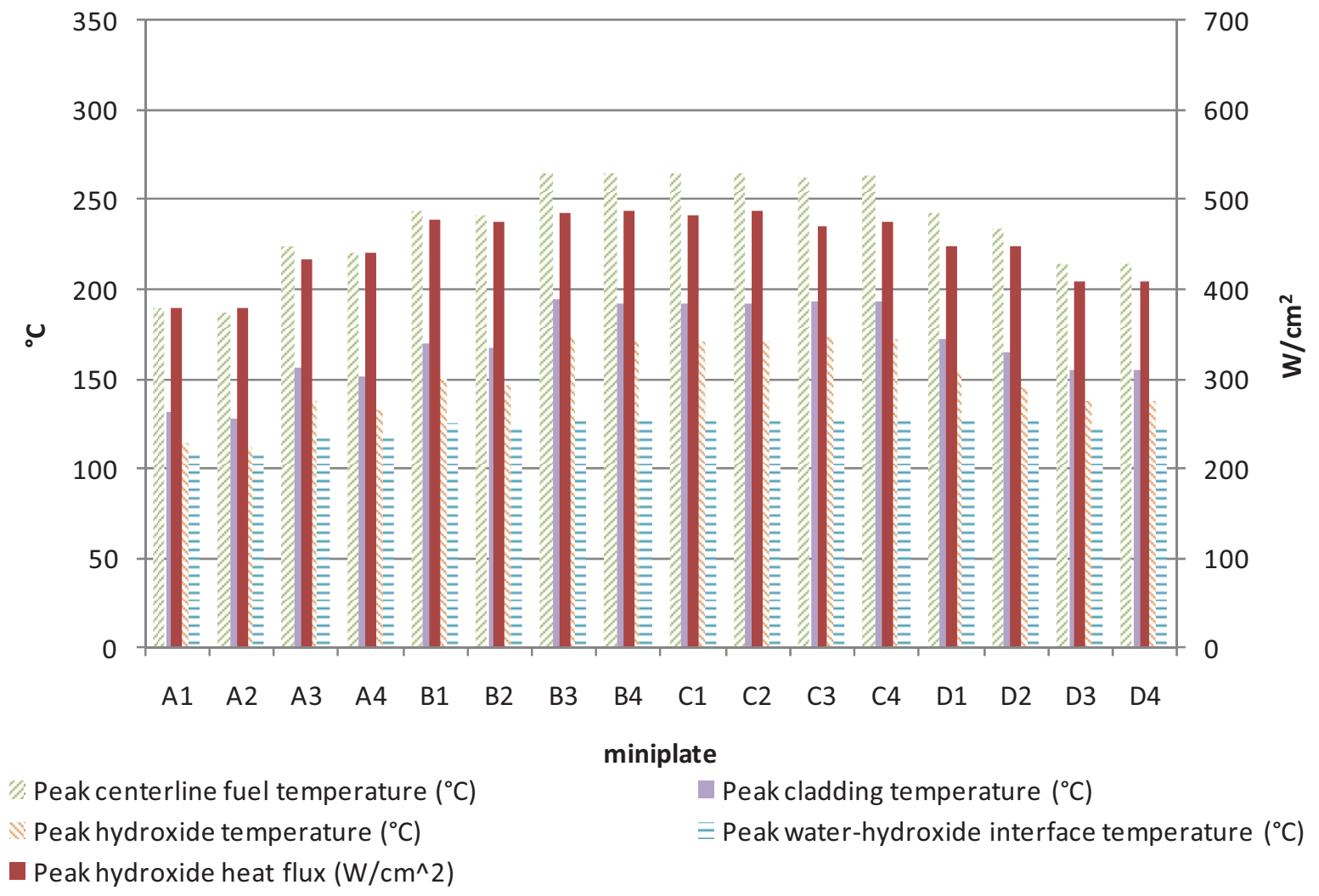

Figure 11. Predicted thermal behavior at MOC (18 EFPD).

Table 8. Summary of thermal predictions for MOC (18 EFPD).

\begin{tabular}{|c|c|c|c|c|c|}
\hline \multirow{2}{*}{ Plate } & $\begin{array}{c}\text { Peak Hydroxide } \\
\text { Heat Flux }\end{array}$ & $\begin{array}{c}\text { Peak Centerline } \\
\text { Fuel Temperature }\end{array}$ & $\begin{array}{c}\text { Peak Cladding } \\
\text { Temperature }\end{array}$ & $\begin{array}{c}\text { Peak Hydroxide } \\
\text { Temperature }\end{array}$ & $\begin{array}{c}\text { Peak Water- } \\
\text { Hydroxide Interface } \\
\text { Temperature }\end{array}$ \\
\cline { 2 - 6 } & $\mathbf{W} / \mathbf{c m}^{2}$ & ${ }^{\circ} \mathbf{C}$ & ${ }^{\circ} \mathbf{C}$ & 115 & 110 \\
\hline A1 & 378 & 190 & 131 & 113 & 110 \\
\hline A2 & 378 & 187 & 128 & 138 & 118 \\
\hline A3 & 432 & 224 & 156 & 133 & 119 \\
\hline A4 & 441 & 221 & 151 & 150 & 126 \\
\hline B1 & 477 & 244 & 170 & 147 & 125 \\
\hline B2 & 475 & 241 & 167 & 173 & 128 \\
\hline B3 & 485 & 266 & 194 & 171 & 128 \\
\hline B4 & 488 & 264 & 192 & 171 & 128 \\
\hline C1 & 483 & 264 & 192 & 171 & 129 \\
\hline C2 & 487 & 265 & 192 & 173 & 129 \\
\hline C3 & 470 & 263 & 193 & 173 & 129 \\
\hline C4 & 476 & 263 & 193 & 154 & 127 \\
\hline D1 & 447 & 242 & 173 & 146 & 127 \\
\hline D2 & 447 & 234 & 164 & 138 & 124 \\
\hline D3 & 408 & 214 & 155 & 138 & 124 \\
\hline D4 & 409 & 215 & 156 & & \\
\hline
\end{tabular}




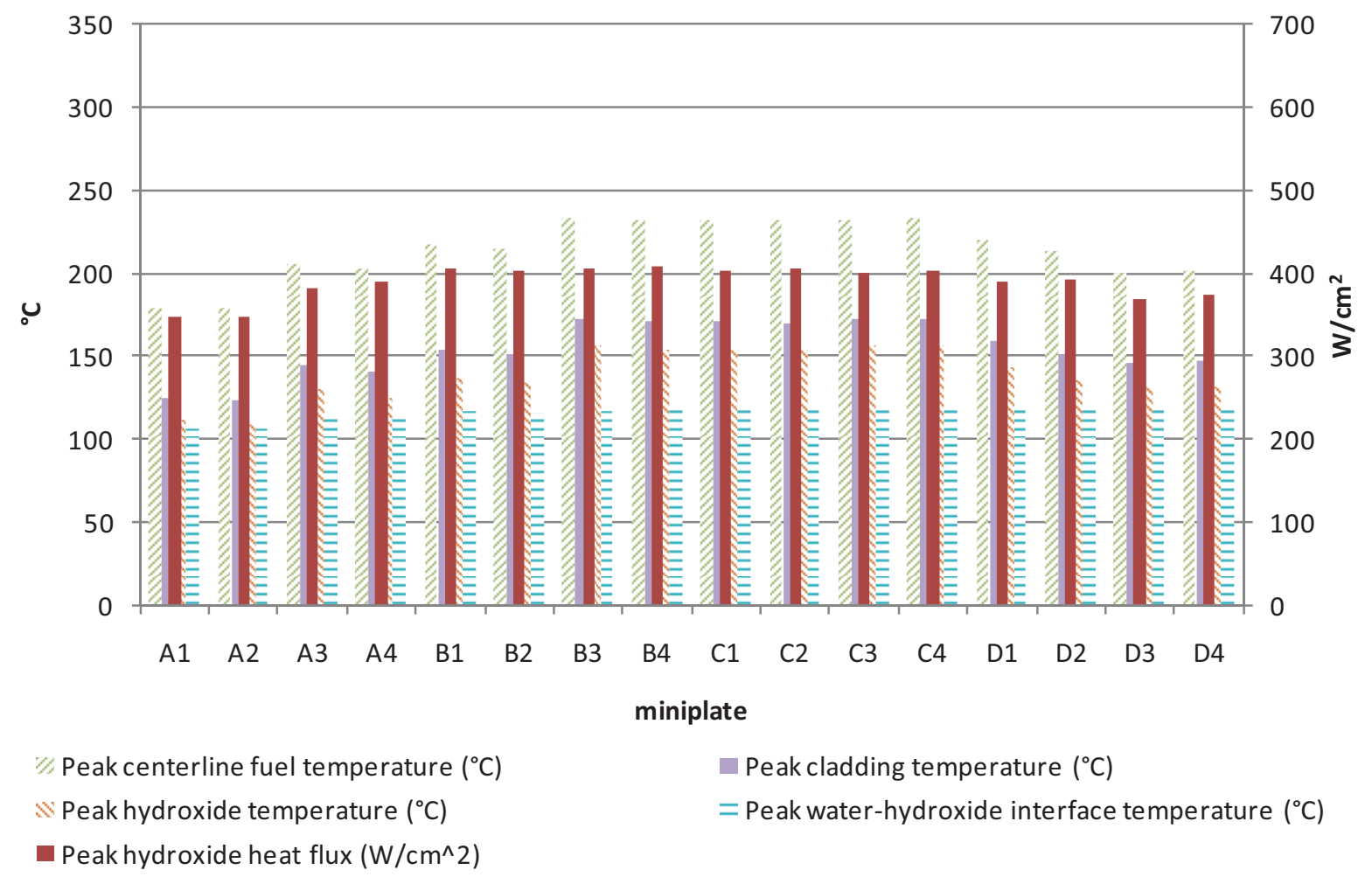

Figure 12. Predicted thermal behavior at MOC (36 EFPD).

Table 9. Summary of thermal predictions for MOC (36 EFPD).

\begin{tabular}{|c|c|c|c|c|c|}
\hline \multirow{2}{*}{ Plate } & $\begin{array}{c}\text { Peak Hydroxide } \\
\text { Heat Flux }\end{array}$ & $\begin{array}{c}\text { Peak Centerline } \\
\text { Fuel Temperature }\end{array}$ & $\begin{array}{c}\text { Peak Cladding } \\
\text { Temperature }\end{array}$ & $\begin{array}{c}\text { Peak Hydroxide } \\
\text { Temperature }\end{array}$ & $\begin{array}{c}\text { Peak Water- } \\
\text { Hydroxide Interface } \\
\text { Temperature }\end{array}$ \\
\cline { 2 - 6 } & $\mathbf{W} / \mathbf{c m}^{\mathbf{2}}$ & ${ }^{\circ} \mathbf{C}$ & ${ }^{\circ} \mathbf{C}$ & ${ }^{\circ} \mathbf{C}$ & ${ }^{\circ} \mathbf{C}$ \\
\hline A1 & 346 & 179 & 125 & 111 & 106 \\
\hline A2 & 348 & 178 & 123 & 108 & 106 \\
\hline A3 & 382 & 205 & 145 & 129 & 112 \\
\hline A4 & 390 & 202 & 141 & 124 & 113 \\
\hline B1 & 404 & 216 & 153 & 137 & 116 \\
\hline B2 & 402 & 213 & 151 & 134 & 116 \\
\hline B3 & 405 & 232 & 172 & 156 & 117 \\
\hline B4 & 407 & 231 & 171 & 153 & 118 \\
\hline C1 & 404 & 231 & 171 & 153 & 118 \\
\hline C2 & 406 & 231 & 170 & 153 & 119 \\
\hline C3 & 399 & 232 & 173 & 156 & 119 \\
\hline C4 & 402 & 232 & 173 & 156 & 119 \\
\hline D1 & 391 & 219 & 159 & 142 & 117 \\
\hline D2 & 392 & 213 & 152 & 135 & 118 \\
\hline D3 & 370 & 199 & 146 & 131 & 131 \\
\hline D4 & 373 & 201 & 147 & & \\
\hline
\end{tabular}




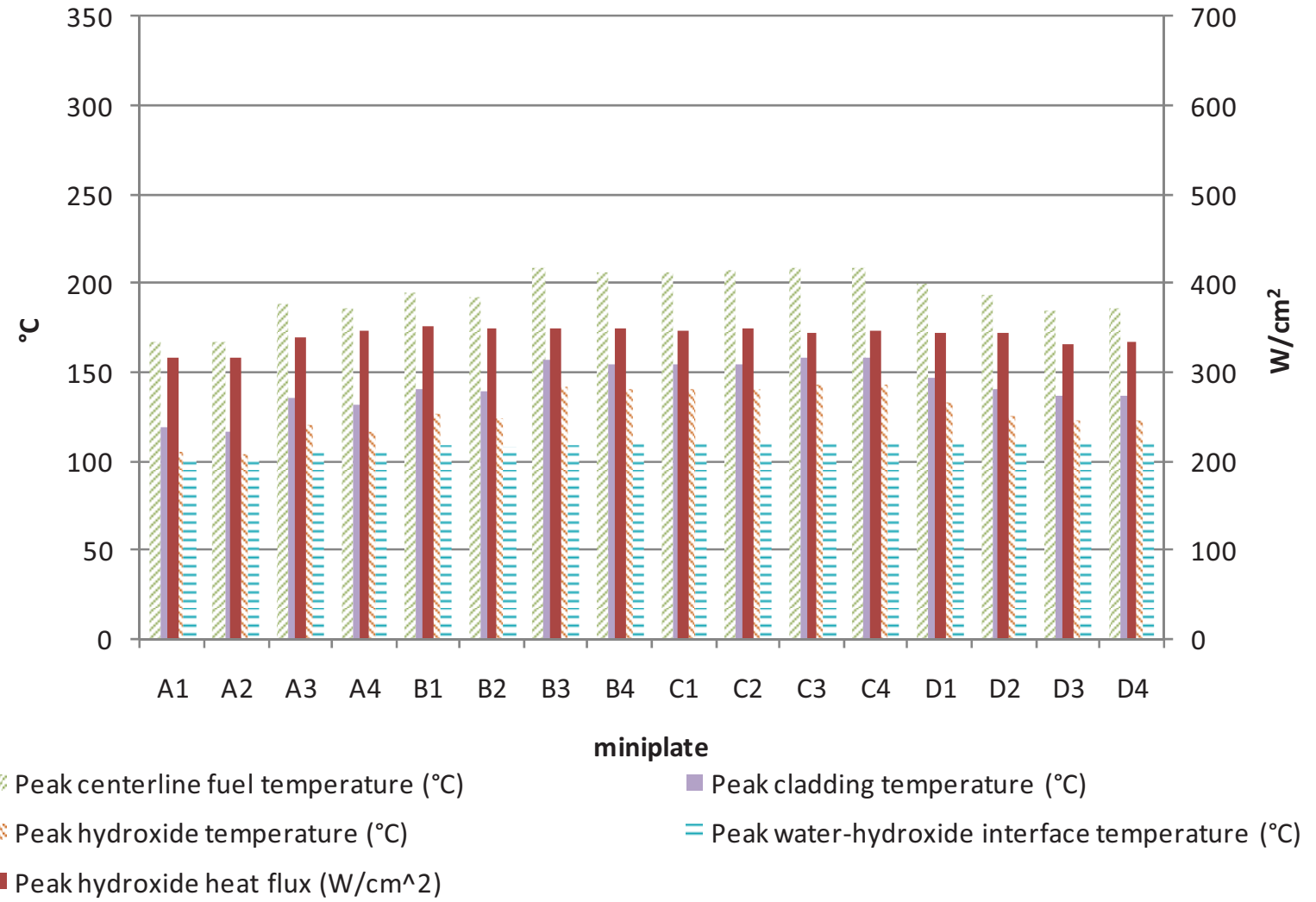

Figure 13. Predicted thermal behavior at EOC (48.9 EFPD).

Table 10. Summary of thermal predictions for EOC (48.9 EFPD).

\begin{tabular}{|c|c|c|c|c|c|}
\hline \multirow{2}{*}{ Plate } & $\begin{array}{c}\text { Peak Hydroxide } \\
\text { Heat Flux }\end{array}$ & $\begin{array}{c}\text { Peak Centerline } \\
\text { Fuel Temperature }\end{array}$ & $\begin{array}{c}\text { Peak Cladding } \\
\text { Temperature }\end{array}$ & $\begin{array}{c}\text { Peak Hydroxide } \\
\text { Temperature }\end{array}$ & $\begin{array}{c}\text { Peak Water- } \\
\text { Hydroxide Interface } \\
\text { Temperature }\end{array}$ \\
\cline { 2 - 6 } & $\mathbf{W} / \mathbf{c m}^{\mathbf{2}}$ & ${ }^{\circ} \mathbf{C}$ & ${ }^{\circ} \mathbf{C}$ & ${ }^{\circ} \mathbf{C}$ & 106 \\
\hline A1 & 316 & 168 & 119 & 104 & 102 \\
\hline A2 & 317 & 167 & 117 & 121 & 106 \\
\hline A4 & 338 & 188 & 136 & 117 & 107 \\
\hline B1 & 346 & 186 & 132 & 127 & 109 \\
\hline B2 & 351 & 196 & 141 & 124 & 108 \\
\hline B3 & 349 & 193 & 139 & 142 & 1109 \\
\hline B4 & 350 & 208 & 157 & 141 & 110 \\
\hline C1 & 346 & 207 & 155 & 141 & 110 \\
\hline C2 & 349 & 207 & 155 & 141 & 111 \\
\hline C3 & 345 & 207 & 155 & 143 & 112 \\
\hline C4 & 347 & 208 & 158 & 143 & 112 \\
\hline D1 & 344 & 209 & 158 & 133 & 112 \\
\hline D2 & 344 & 200 & 147 & 126 & 112 \\
\hline D3 & 331 & 194 & 141 & 123 & \\
\hline D4 & 334 & 184 & 137 & 123 & \\
\hline
\end{tabular}



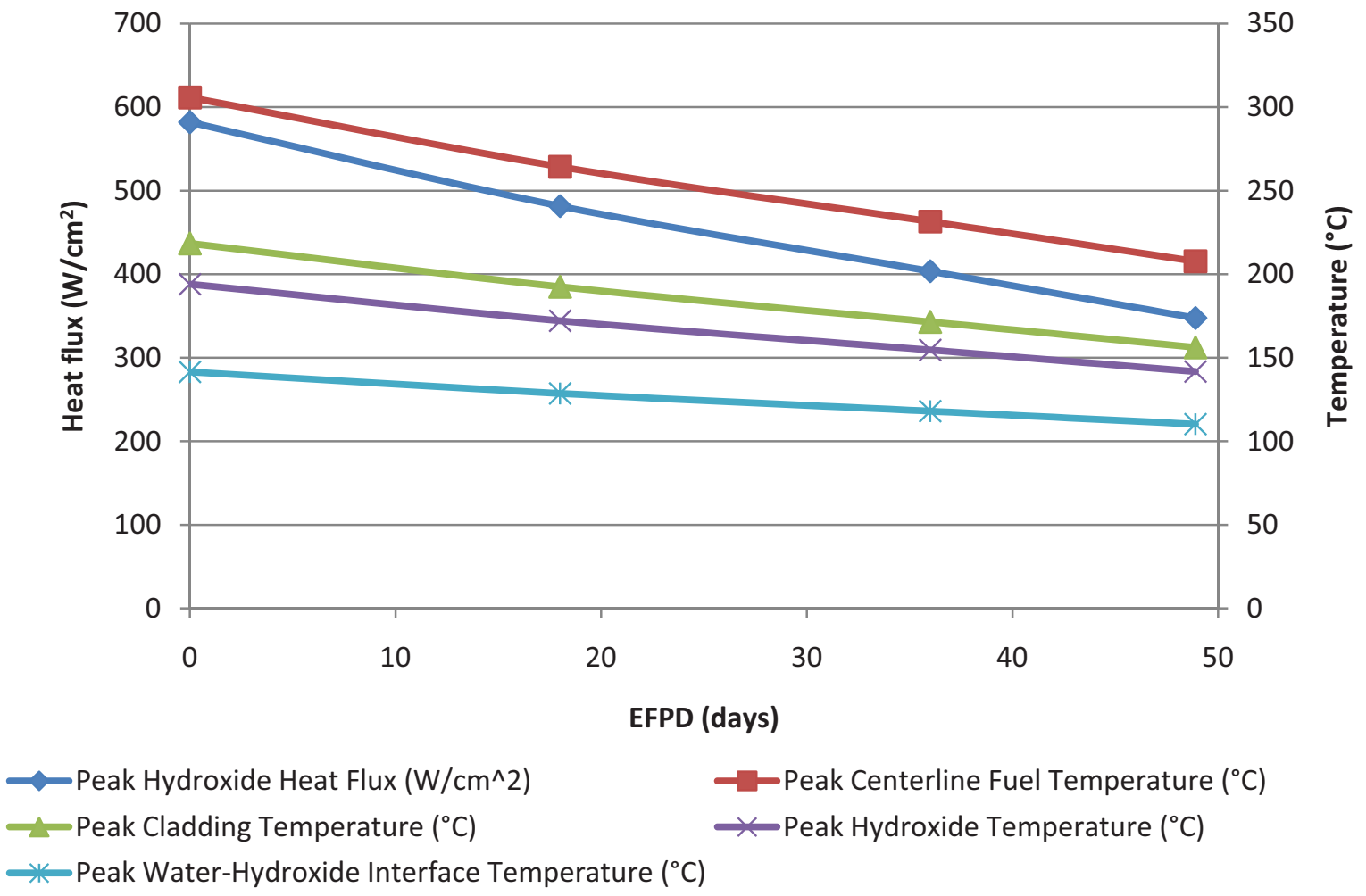

Figure 14. Variation with irradiation time of heat flux and peak temperatures for the six hottest miniplates.

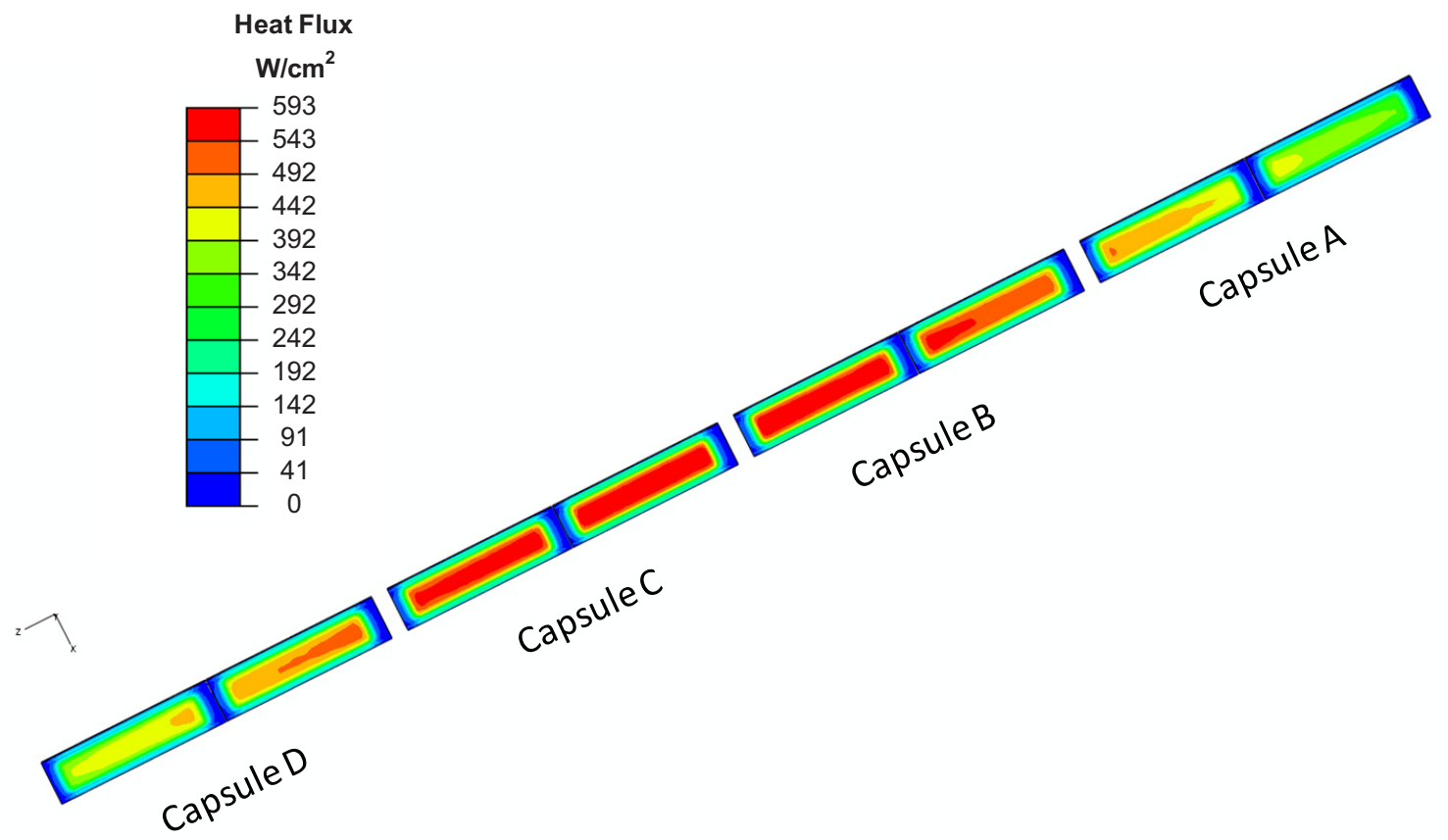

Figure 15. Variation of miniplate hydroxide heat flux with axial position. 


\section{SUMMARY}

The GTL-1 experiment was conducted to assess corrosion the performance of the proposed BFFL booster fuel at heat flux levels $\sim 30 \%$ above the design operating condition. Sixteen miniplates fabricated from $25 \%$ enriched, high-density $\mathrm{U}_{3} \mathrm{Si}_{2} / \mathrm{Al}$ dispersion fuel with 6061 aluminum cladding were subjected to peak BOC heat fluxes ranging from $411 \mathrm{~W} / \mathrm{cm}^{2}$ to $593 \mathrm{~W} / \mathrm{cm}^{2}$. Miniplates fabricated with three different fuel variations (without fines, annealed, and with standard powder) exhibited negligible irradiation-induced swelling and a normal fission density gradient (Robinson 2008). Both the standard and the modified prefilm procedures produced hydroxide films that adequately protected the miniplates from excessive corrosion.

A detailed finite element model was constructed to calculate temperatures and heat flux for an as-run cycle average effective south lobe power of $25.4 \mathrm{MW}(\mathrm{t})$. Results of the thermal analysis are given at four times during the cycle: BOC at 0 EFPD, MOC at 18 EFPD, MOC at 36 EFPD, and EOC at 48.9 EFPD. The highest temperatures and heat fluxes occur at the BOC and decrease in a linear manner throughout the cycle.

Miniplate heat flux levels and fuel, cladding, hydroxide, and coolant-hydroxide interface temperatures were calculated using the average measured hydroxide thickness on each miniplate. The hydroxide layers are the largest on miniplates nearest to the core midplane, where heat flux and temperature are highest. As shown in Figure 8, the hydroxide layer thickness increases monotonically with peak hydroxide temperature. The hydroxide layer exhibits a marked increase in thickness for the hottest plates. The reported thicknesses are clustered into three groupings at high, mid and low hydroxide temperatures. The six hottest miniplates $(\mathrm{B} 3, \mathrm{~B} 4, \mathrm{C} 1, \mathrm{C} 2, \mathrm{C} 3$, and $\mathrm{C} 4)$ have the following thermal characteristics at BOC:

- Peak fuel centerline temperature $>300^{\circ} \mathrm{C}$

- $\quad$ Peak cladding temperature $>200^{\circ} \mathrm{C}$

- Peak hydroxide temperature $>190^{\circ} \mathrm{C}$

- Peak hydroxide-water interface temperature $>140^{\circ} \mathrm{C}$

- Peak heat flux $>565 \mathrm{~W} / \mathrm{cm}^{2}$. 


\section{RECOMMENDATIONS FOR FUTURE STUDIES}

The following recommendations are provided to gain a better understanding of the miniplate surface hydroxide layer formed during irradiation.

1. Recommendation: Rerun the thermal analysis using ABAQUS CFD.

Rationale: The existing thermal models for RERTR and GTL-1 are constructed using a bulk flow approach to modeling of the water channels. Modeling the flow channels using the CFD tool that became available in the 6.10 release of ABAQUS would provide details on the flow behavior through the test train. Researchers have found the properties of the boehmite layer strongly depend upon the agitation, atmosphere, and pressure of the water flow (Wang 2009). There are significant differences between hydroxide layers formed under static versus flowing conditions. This analysis may shed light on the differences in measured hydroxide thickness between the GTL-1 and the RERTR miniplates (Robinson and Finlay 2007). The GTL-1 design holds two plates per level, whereas the RERTR design holds four plates per level. The flow channels adjacent to the miniplates are more than $50 \%$ larger for the GTL-1 test train than for the RERTR test train. The RERTR-12 design relies upon a total of five coolant channels - three inner flow channels that are $0.234 \mathrm{~cm}$ wide and two outer flow channels that are $0.146 \mathrm{~cm}$ wide - to provide cooling to the miniplates (Roth 2009). In comparison, the GTL-1 design has three water coolant channels that are $0.36 \mathrm{~cm}$ wide adjacent to the miniplates.

2. Recommendation: Perform in-depth PIE of the hydroxide layer formed on the miniplates.

Rationale: Thicker hydroxide layers were observed on the GTL-1 miniplates wherein the peak hydroxide temperature exceeded the prefilm application temperature of $185^{\circ} \mathrm{C}$. Further PIE is recommended to investigate possible microstructural changes in the hydroxide layers on these miniplates. Further PIE of the hydroxide phase and composition should be conducted, including microstructural analysis and x-ray diffraction to determine phase composition, crystal size, morphology, and porosity. The presence of precipitates protruding from the surface can dramatically increase the surface texture of the cladding and skew the eddy current measurements. Relative roughness of the discolored areas of the miniplates should be examined and an analysis should be performed to quantify concentrations of $\mathrm{Fe}, \mathrm{Cu}, \mathrm{Si}, \mathrm{Mg}$, and $\mathrm{Mn}$. The effect of microstructure on the thermophysical properties and stability of the hydroxide layer should be quantified. The thermal conductivity of hydroxide films formed during irradiation in the reactor may be significantly lower than ex-reactor formed films (Polkinghorne and Lacy 1991). A film with a lower thermal conductivity reduces heat transfer from the fuel to the coolant, thus leading to higher plate temperatures. Additional work in this area would aid in establishing a safe maximum hydroxide operating temperature to prevent excessive growth that could lead to fuel plate failure.

3. Recommendation: Conduct a well-controlled, fundamental study on irradiated hydroxide layer to elucidate the mechanisms of hydroxide layer growth.

Rationale: It is well established in literature that the corrosion conditions in the reactor differ significantly from those in the autoclave (Wintergerst 2009). The corrosion product that forms on the surface of the fuel cladding during irradiation is typically much thicker than that obtained in the autoclave. Thermal hydraulic conditions (e.g., coolant velocity, turbulence, temperature), surface radiolysis, and water chemistry are factors that can contribute to these differences. The presence of crud (nonfilterable solids from the reactor coolant), contaminants or precipitates can drastically alter the boehmite surface texture and composition. Degradation of the electropositive passivation of the hydroxide layer surrounding the surface precipitate particles should be examined. A well-controlled study is needed to develop a fundamental understanding of how the hydroxide grows and changes during reactor operation. 
4. Recommendation: Effects caused by the chemical reaction between fuel and matrix materials should be evaluated.

Rationale: Prior experiments of $\mathrm{U}_{3} \mathrm{Si}_{2} / \mathrm{Al}$ fuel irradiated at the High Flux Isotope Reactor showed that the aluminum- $\mathrm{U}_{3} \mathrm{Si}_{2}$ interdiffusion process results in the formation of the intermetallic compound $\mathrm{U}(\mathrm{AlSi})_{3}$ in the diffusion zone at the $\mathrm{U}_{3} \mathrm{Si}_{2} / \mathrm{Al}$ interface. Hofman et al. (1996) observed that these interaction zones grow in extent as operating temperature and fission rates are increased. The BFFL Final Report (INL 2009) includes PIE images that reveal aluminum silicide zones around the fuel particles. Some fuel particles appear to be $\mathrm{U}_{3} \mathrm{Si}$ rather than $\mathrm{U}_{3} \mathrm{Si}_{2}$, which can be attributed to the aluminum-silicon reaction depleting silicon from the uranium silicide. Thermal effects from the heat of reaction (approximately $350 \mathrm{~J} / \mathrm{g}$ of $\mathrm{U}_{3} \mathrm{Si}_{2}$ reacted) (NUREG-1313 1988) are $26.5 \mathrm{~J} / \mathrm{cm}^{2}$ for each miniplate, producing a very small heat release for the large reaction times associated with diffusion (Hofman et al. 1996). The calculations presented in this report do not include radiation-induced changes to the thermophysical properties. As the irradiation cycle progressed, the thermophysical properties of the fuel employed by the ABAQUS model were not varied to reflect changes in the fuel (burnup, interdiffusion, etc.) because no such data was available. 


\section{REFERENCES}

Beckwith, R., 2011, ATR coolant chemistry history, personal communication.

Bourns, W. T., 1968, “Corrosion Testing of Uranium Silicide Fuel Specimens,” AECL-2718, Atomic Energy of Canada Limited, September 1968.

Byalobzheskii, A. V., 1963, "The Effect of Neutron Irradiation on the Corrosion of Aluminum in Water," Institute of Physical Chemistry, Academy of Sciences, USSR, May 1963.

Dassault Systèmes Simulia Corp., 2007, ABAQUS/Standard, Version 6.7-3 (2007).

Guillen, D. P., 2008, “Thermal Analysis of Gas Test Loop-1 (GTL-1) Miniplate Irradiation Experiment," ECAR-62, Idaho National Laboratory.

Guillen, D. P., and Murray, P., 2009, "Thermal Analysis of Gas Test Loop-1 (GTL-1) Miniplate Irradiation Experiment," Idaho National Laboratory, Proceedings of the $13^{\text {th }}$ Nuclear Thermal Hydraulics Meeting (Nureth-13), September 28-October 1, 2009, Kanazawa, Japan.

Guillen, D. P., and Yoder, T. S., 2008, “Thermal Hydraulic Effects of Fuel Plate Surface Roughness," Nuclear Engineering and Design, Vol. 238, pp. 2480-2483.

Hayes, S. L., 2006, "High Temperature Performance of Silicide Dispersion Fuels,” EDF-7450, Idaho National Laboratory.

Hayes, S. L., 2008, " $\mathrm{U}_{3} \mathrm{Si}_{2} / \mathrm{Al}$ Miniplate Irradiation Test Plan to Support the BFFL Booster Fuel Concept," PLN-2735, Idaho National Laboratory, February 2008.

Hofman, G. L., et al., 1996, "Aluminum- $\mathrm{U}_{3} \mathrm{Si}_{2}$ Interdiffusion and its Implications for the Performance of Highly Loaded Fuel Operating at Higher Temperatures and Fission Rates," in Proc. of the 19th International Meeting on Reduced Enrichment for Research and Test Reactors, Seoul, Korea, October 1996.

Incropera, F. P. and DeWitt, D. P., 2002, Fundamentals of Heat and Mass Transfer, $5^{\text {th }}$ ed., John Wiley \& Sons, New York, 2002.

INL, 2009, "Boosted Fast Flux Loop Final Report," Idaho National Laboratory External Report, INL/EXT-09-16413, Idaho National Laboratory, July 2009.

Leenaers, A., et al., 2004, "Microstructure of $\mathrm{U}_{3} \mathrm{Si}_{2}$ Fuel Plates Submitted to a High Heat Flux," Journal of Nuclear Materials, Vol. 327, pp. 121-129.

Longhurst, G. R., and Khericha, S. T., 2005, “Boosted Fast Flux Loop Technical and Functional Requirements,” Draft, Rev. A, INL/EXT-04-02273, Idaho National Laboratory, July 2005.

Murray, P. E., 2008, "Validation of ABAQUS Standard 6.7-3 Heat Transfer," ECAR-131, Idaho National Laboratory, January 30, 2008.

Perez, D. M., and Chang, G. S., 2010, “As-Run Neutronics Analysis of the GTL-1 Experiment Irradiated in ATR South Flux Trap,” ECAR-1245, Idaho National Laboratory.

Perry, R. H., and Green, D. W., 1997, Perry's Chemical Engineers' Handbook, $7^{\text {th }}$ Edition, McGraw-Hill, 1997.

Polkinghorne, S. T., and Lacy, J. M., 1991, Thermophysical and Mechanical Properties of ATR Core Materials, Idaho National Laboratory, August 1991.

Robinson, A. B., 2008, “GTL Non-Destructive Examination Results,” ECAR-677, Idaho National Laboratory, July 24, 2008. 
Robinson, A. G., and Finlay, M. R., 2007, "RERTR-7 Post Irradiation Examination (PIE) Letter Report," INL/EXT-07-13271, Idaho National Laboratory, September 2007.

Roth, G. A., 2008, "RERTR-12 Thermal and Hydraulic Analysis Report," ECAR-768, Idaho National Laboratory, September 29, 2008.

Shaber, E., 2009, email communication, December 22, 2009.

Shaber, E., and Hofman, G., 2005, “Corrosion Minimization for Research Reactor Fuel," Idaho National Laboratory, INL/EXT-05-00256, Idaho National Laboratory, June 2005.

NUREG-1313, 1988, "Safety Evaluation Report Related to the Evaluation of Low-Enriched Uranium Silicide-Aluminum Dispersion Fuel for Use in Non-Power Reactors," U.S. Nuclear Regulatory Commission, July 1988.

"Upgraded Final Safety Analysis Report for the Advanced Test Reactor," Idaho National Laboratory, SAR-153, Chapter 5 - Primary Coolant System, Rev. 14, February 15, 2011.

Wachs, D. M., 2006, “GTL Miniplate Experiment Flow Test,” EDF-7531, Idaho National Laboratory, November 2006.

Wang, J. Q., et al., 2009, "Hydrothermal Transformation of Bayerite to Boehmite." Science of Advanced Materials, Vol. 1, Issue 1, pp. 77-85.

Wintergerst, M. et al., 2009, "Corrosion of the AlFeNi Alloy used for the Fuel Cladding in the Jules Horowitz Research Reactor," Journal of Nuclear Materials, Vol. 393, pp. 369-380 


\section{APPENDIX}

THERMOPHYSICAL PROPERTIES OF MINIPLATE MATERIALS USED IN THE ANALYSIS 


\section{APPENDIX}

The mophysical properties for aluminun alloy 6061 (Thermophysical and Wechanical Properties of A TR Core Materials, EG\&G baho, Inc., Report No. PG-T-91-031, August 1991):

$\mathrm{I}_{3 \mathrm{l} 6061}=\left(\begin{array}{c}400 \\ 500 \\ 600 \\ 00 \\ 900 \\ 855\end{array}\right)^{\mathrm{K}}$

$\mathrm{T}-\frac{\mathrm{T}_{\mathrm{al} 6061}-273 \mathrm{~K}}{1 \cdot \mathrm{K}} \quad \mathrm{T}=\left(\begin{array}{c}127 \\ 227 \\ 327 \\ 427 \\ 527 \\ 562\end{array}\right)$

P.16061 $=2702 \cdot \frac{\mathrm{bg}}{\mathrm{m}^{2}}$

Pal $6661-0098 \cdot \frac{\mathrm{Ib}}{\mathrm{in}^{3}}$ 


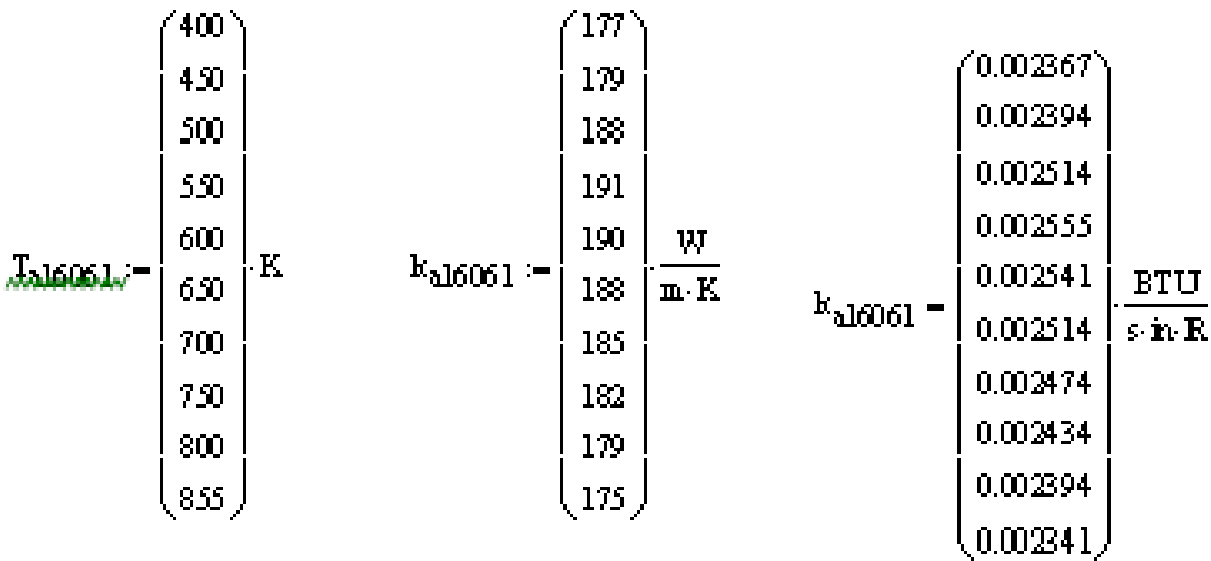

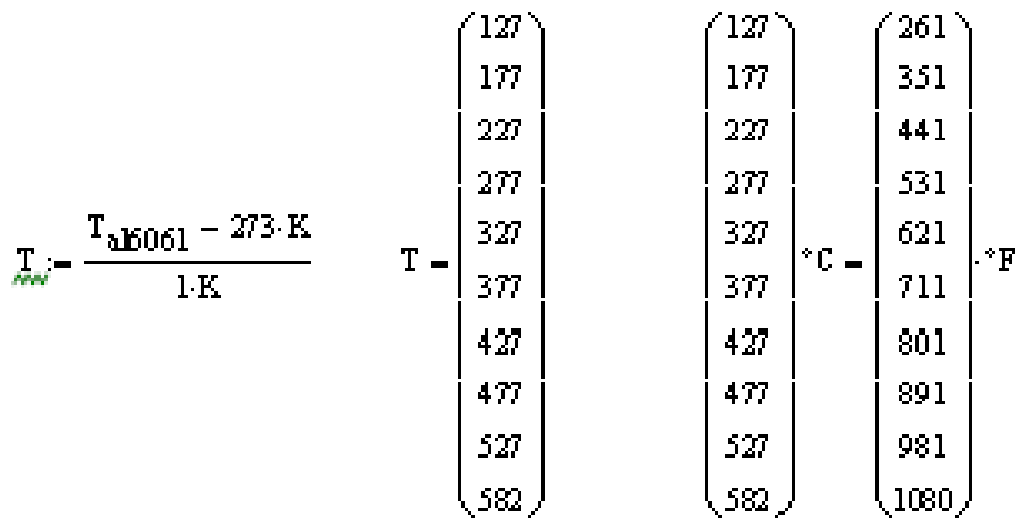

$$
\begin{array}{lll}
\xi_{n}=0.09 \quad \text { at } 212{ }^{\circ} \mathrm{F} & \begin{array}{l}
\text { Enissivity from Holman, J.P. Heat Transter, Me Graw } \\
\text { Hill, Ninth Edition, 2002, P. } 607
\end{array}
\end{array}
$$

Thermophysical properties for boehmite (Thermophysi oal and Mechanical

Properties of A TR Core Materials, EG\&G Uaho, Inc., Report No. P G-T-91-031. A.ugust $1991 \mathrm{j}$ :

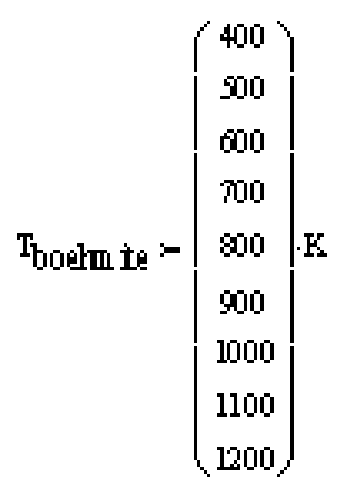

$$
C_{\mathrm{p}}=\left(\begin{array}{l}
\mathrm{B} 49 \\
1538 \\
1704 \\
1844 \\
1999 \\
2049 \\
21 \mathrm{~B} \\
2151 \\
2164
\end{array}\right) \cdot \frac{\mathrm{J}}{\mathrm{b} \cdot \mathrm{K}} \mathrm{P}=\left(\begin{array}{c}
0322 \\
0367 \\
0.407 \\
0.44 \\
0.468 \\
0.499 \\
0.505 \\
0.514 \\
0.517
\end{array}\right) \cdot \frac{\mathrm{BTU}}{\mathbf{b} \cdot \mathrm{R}}
$$




$$
\begin{aligned}
& \text { Pboekmite }=3010 \cdot \frac{\mathrm{kg}}{\mathrm{m}^{3}} \quad \text { Ptoekmite }-0.100 \cdot \frac{\mathrm{Ib}}{\dot{\mathbf{n}}^{3}} \\
& k_{\text {boekmite }}=225 \frac{\mathrm{W}}{\mathrm{m} \cdot \mathrm{K}} \quad \mathrm{k}_{\text {boekm te }}-3000 \times 10^{-5} \cdot \frac{\mathrm{BTU}}{\mathrm{s} \cdot \mathrm{m} \mathrm{R}}
\end{aligned}
$$

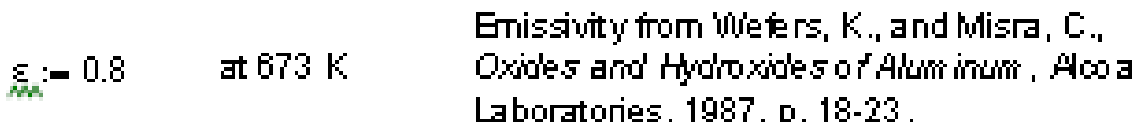

Themophysical properties for $\mathrm{U}_{2} \mathrm{Si}_{2}$ - $\mathrm{Al}$ dispersion fuel (Research Reactor Core Corwersion Guidebook, IAEA-TECDOC-643, Vol 4: Fuels, Appendices I-K):

$$
\mathrm{T}_{\mathrm{u}}:=\left(\begin{array}{c}
400 \\
500 \\
600 \\
700 \\
800 \\
900 \\
1000 \\
1100 \\
1200
\end{array}\right) \cdot \mathrm{K} \quad \mathrm{T}_{\mathrm{usi}}:-\frac{\mathrm{T}_{\mathrm{u}}-273 \cdot \mathrm{K}}{1 \cdot \mathrm{K}} \mathrm{T}_{\mathrm{u}}-\left(\begin{array}{l}
127 \\
227 \\
327 \\
427 \\
527 \\
627 \\
727 \\
827 \\
927
\end{array}\right) \cdot\left(\begin{array}{l}
127 \\
227 \\
327 \\
427 \\
527 \\
627 \\
727 \\
827 \\
927
\end{array}\right) \cdot\left(\begin{array}{l}
261 \\
441 \\
621 \\
801 \\
981 \\
1161 \\
1341 \\
1521 \\
1201
\end{array}\right) \cdot{ }^{\circ} \mathrm{F}
$$

$$
S_{\mathrm{p}}:-\left(0.199+0.000104 \cdot \mathrm{T}_{\mathrm{uxi}}\right) \frac{\mathrm{J}}{\mathrm{gm} \cdot \mathrm{K}}
$$

$c_{p}$ values are or $\mathrm{U}_{3} \mathrm{Si}_{2}$ and don't account for aluminum dispersion, which would increase $c_{p}$. Theretore, ABAOUS calculations are conseruative. 


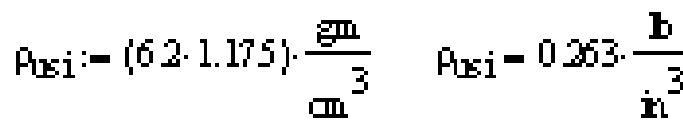

$$
\begin{aligned}
& 0.051 \\
& 0056 \\
& \mathrm{~b}_{\mathrm{zEi} i}:-2 \mathrm{~J} \cdot \frac{\mathrm{W}}{\mathrm{II} \cdot \mathrm{K}}
\end{aligned}
$$

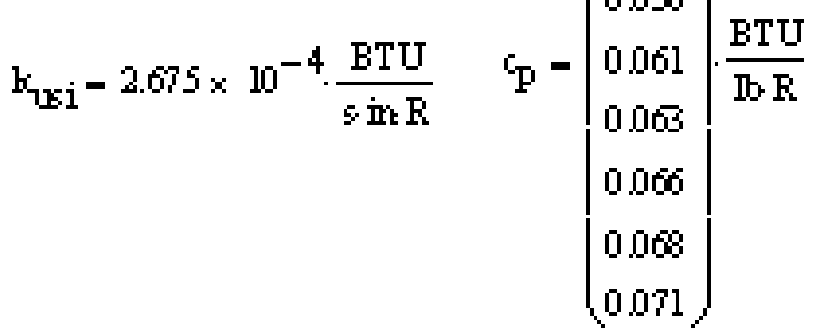

